\title{
Experimental Investigation of the Phase Equilibria in the Al-Mn-Zn System at $400^{\circ} \mathrm{C}$
}

\author{
Tian Wang, Dmytro Kevorkov, Ahmad Mostafa, and Mamoun Medraj \\ Department of Mechanical Engineering, Concordia University, 1455 de Maisonneuve Boulevard West, \\ Montreal, QC, Canada H3G $1 M 8$ \\ Correspondence should be addressed to Mamoun Medraj; mmedraj@encs.concordia.ca
}

Received 5 April 2014; Accepted 16 June 2014; Published 17 July 2014

Academic Editor: Alok Singh

Copyright (C) 2014 Tian Wang et al. This is an open access article distributed under the Creative Commons Attribution License, which permits unrestricted use, distribution, and reproduction in any medium, provided the original work is properly cited.

Al-Mn-Zn ternary system is experimentally investigated at $400^{\circ} \mathrm{C}$ using diffusion couples and key alloys. Phase relationships and homogeneity ranges are determined for binary and ternary compounds using EPMA, SEM/EDS, and XRD. Reported ternary compound T3 $\left(\mathrm{Al}_{11} \mathrm{Mn}_{3} \mathrm{Zn}_{2}\right)$ is confirmed in this study and is denoted as $\tau_{2}$ in this paper. Two new ternary compounds ( $\tau_{1}$ and $\tau_{3}$ ) are observed in this system at $400^{\circ}$ C. $\tau_{1}$ is determined as a stoichiometric compound with the composition of $\mathrm{Al}_{31} \mathrm{Mn}_{8} \mathrm{Zn}_{11} . \tau_{3}$ has been found to have homogeneity range of $\mathrm{Al}_{x} \mathrm{Mn}_{y} \mathrm{Zn}_{z}(x=9-13$ at $\% ; y=11-15$ at $\% ; z=75-77$ at $\%$ ). The binary compounds $\mathrm{Al}_{4} \mathrm{Mn}$ and $\mathrm{Al}_{11} \mathrm{Mn}_{4}$ exhibit limited solid solubility of around 6 at\% and 4 at $\% \mathrm{Zn}$, respectively. Terminal solid solution $\mathrm{Al}_{8} \mathrm{Mn}_{5}$ is found to have maximum ternary solubility of about 10 at $\% \mathrm{Zn}$. In addition, ternary solubility of $\mathrm{Al}$-rich $\beta-\mathrm{Mn}^{\prime}$ at $400^{\circ} \mathrm{C}$ is determined as 4 at $\% \mathrm{Zn}$. Zn-rich $\beta$ - $\mathrm{Mn}^{\prime \prime}$ has a ternary solubility of 3 at $\% \mathrm{Al}$. The solubility of $\mathrm{Al}$ in $\mathrm{Mn}_{5} \mathrm{Zn}_{21}$ is measured as 5 at\%. Based on the current experimental results, the isothermal section of $\mathrm{Al}-\mathrm{Mn}-\mathrm{Zn}$ ternary system at $400^{\circ} \mathrm{C}$ has been constructed.

\section{Introduction}

Automotive industry represents one of the most important markets for aluminum alloys. The use of aluminum and its alloys offers considerable potential to reduce the weight of an automobile body or engine without compromising performance and safety [1]. Many different elements including $\mathrm{Mg}, \mathrm{Cu}, \mathrm{Zn}, \mathrm{Mn}, \mathrm{Si}$, and so forth are used to improve the properties of $\mathrm{Al}$ alloy for specific applications. $\mathrm{Al}-\mathrm{Zn}$ based alloys have high strength and hardness, improved creep, wear resistance, and low density. It is well known that a small amount of $\mathrm{Mn}$ added to $\mathrm{Al}$ alloys plays a positive role in improving the fracture toughness, recrystallization, grain refinement, and resistance to stress corrosion fatigue of these alloys [1-3]. Because the Al-Mn- $\mathrm{Zn}$ system is an important ternary system for the development of $\mathrm{Al}$ alloys, it is essential to understand the phase relationships in the system. In addition, this system is an essential subsystem for AZ, AM-series magnesium alloys, high strength steels, and for galvanizing-related alloy systems $[4,5]$.

The three constituent binary systems were reasonably studied. Khan and Medraj [6] reevaluated the Al-Mn system which was in good agreement with most of the experimental results [7-10]. From their work [6], thermodynamic calculation almost reproduced the EPMA results of Minamino et al. [11]. Their calculation was consistent with the observation of Okamoto [12] who suggested a smooth continuous liquidus curve between the terminal $\delta$-phase (BCC) throughout the $\varepsilon$-phase (HCP) as mentioned by Taylor [13]. Al-Zn system was critically reviewed by Wasiur-Rahman and Medraj [14] lately. Their description showed good agreement with most of the experimental results. Mn-Zn system was reviewed by Okamoto and Tanner [15]. They proposed that there could be three possible separated phase fields $\left(\varepsilon, \varepsilon_{1}\right.$, and $\left.\varepsilon_{2}\right)$ in the epsilon phase region. They [15] suggested that $\varepsilon_{1}$ and $\varepsilon_{2}$ phases can possibly be metastable phases, based on the analysis of [16-19]. However, the presence of these separated phase regions has not been validated in the published literature. Recently, Liang et al. [20-22] analyzed $\varepsilon$-phase at $400^{\circ} \mathrm{C}, 500^{\circ} \mathrm{C}$, and $600^{\circ} \mathrm{C}$. Based on their observations, the subdivision of the $\varepsilon$-phase region could not be confirmed.

Up to date little effort has been made to describe the phase relationships in the Al-Mn-Zn ternary system. The partial Al-Mn-Zn liquidus projection near the $\mathrm{Zn}$-rich corner 
was studied by Gebhardt [23]. Later, Raynor and Wakeman [24] synthesized three ternary compounds ( $\mathrm{T} 1: \mathrm{Al}_{24} \mathrm{Mn}_{5} \mathrm{Zn}$, T2: $\mathrm{Al}_{9} \mathrm{Mn}_{2} \mathrm{Zn}$, and T3: $\mathrm{Al}_{11} \mathrm{Mn}_{3} \mathrm{Zn}_{2}$ ) using electrolytic deposition and not by alloying. They [24] pointed out that $\mathrm{Al}_{4} \mathrm{Mn}$ dissolves up to $5.2 \mathrm{wt} \% \mathrm{Zn}$; whereas $\mathrm{Al}_{6} \mathrm{Mn}$ dissolves only 0.78 wt $\% \mathrm{Zn}$. These two compounds were characterized based on the substitution of Mn by $\mathrm{Zn}$ atoms. Subsequently, several researchers [25-28] focused on the crystal structural analysis of the ternary compounds reported by Raynor and Wakeman [24]. Robinson [25] found that T1 was C-centered orthorhombic phase with $a=2.48, b=2.51$, and $c=$ $3.03 \mathrm{~nm}$ lattice parameters. The structure of T3 was found by Damjanovic [26], which also has C-centered orthorhombic unit cell with $a=7.78, b=23.8$, and $c=12.6 \mathrm{~nm}$ lattice parameters. Schaefer et al. [27] showed that addition of $\mathrm{Zn}$ to Al-Mn alloys promoted the formation of decagonal phase. Singh et al. [28] used TEM to examine the formation and the approximant structures of $\mathrm{Al}_{24} \mathrm{Mn}_{5} \mathrm{Zn}$ and $\mathrm{Al}_{12} \mathrm{Mn}_{2.9} \mathrm{Zn}$ (close to $\mathrm{T} 3$ phase) quasicrystals in melt-spun condition. They [28] observed that melt spinning could lead to the formation of icosahedral phase in $\mathrm{Al}_{24} \mathrm{Mn}_{5} \mathrm{Zn}$ and decagonal phase in $\mathrm{Al}_{12} \mathrm{Mn}_{2.9} \mathrm{Zn}$. Up to now, the experimental phase equilibrium information and thermodynamic data are insufficient for the accurate description of this system. Therefore, experimental investigations of the phase equilibrium in the Al-Mn-Zn ternary system are specifically performed in the present work to provide the phase relationships in this system at $400^{\circ} \mathrm{C}$.

\section{Experimental Procedures}

Diffusion couple technique is a powerful and efficient tool for phase diagram determination [29-31]. The layer formation in diffusion couples represents the local equilibria at the interfaces. Ternary diffusion couples may contain two phases in one layer, because of the additional degree of freedom [31]. Thus, three-phase equilibria can be determined at the interfaces of such layers. However, ternary diffusion couples have unpredictable diffusion paths that can lead to omitting some phases. Moreover, slow kinetic formation of some phases may cause the formation of extremely thin layers that might be difficult to be successfully analyzed. Therefore, key alloys are used to verify the phase relationships obtained from diffusion couple experiments. In this work, the experimental procedure was based on the combination of diffusion couple and key alloys techniques. The starting materials for both diffusion couples and key alloys were $\mathrm{Al}$ ingots, with purity $99.7 \%$; Zn rods, with purity $99.99 \%$; and Mn pieces, with purity $99 \%$. All of which were supplied by Alfa Aesar, A Johnson Matthey Company. Alloys were prepared in an induction-melting furnace with a Ta crucible under an argon protective atmosphere. All samples were remelted three times to assure homogeneity. The actual global composition of the prepared samples was determined by inductively coupled plasma/optical emission spectrometry (ICP/OES). The specimens for ICP analysis were taken from 3 different locations of the sample to assure the accuracy of the analysis.
TABLE 1: Terminal compositions of diffusion couples along with annealing time.

\begin{tabular}{lcc}
\hline Diffusion couple number & End-members & Annealing time \\
\hline DC1 & $\mathrm{Al}-\mathrm{Mn}_{11} \mathrm{Zn}_{89}$ & 30 days \\
DC2 & $\mathrm{Mn}-\mathrm{Al}_{94} \mathrm{Zn}_{6}$ & 15 and 25 days \\
DC3 & $\mathrm{Al}-\mathrm{Mn}_{13} \mathrm{Zn}_{87}$ & 30 days \\
DC4 & $\mathrm{Mn}-\mathrm{Al}_{65} \mathrm{Mn}_{30} \mathrm{Zn}_{5}$ & 30 days \\
DC5 & $\mathrm{Al}-\mathrm{Mn}_{32} \mathrm{Zn}_{68}$ & 30 days \\
\hline
\end{tabular}

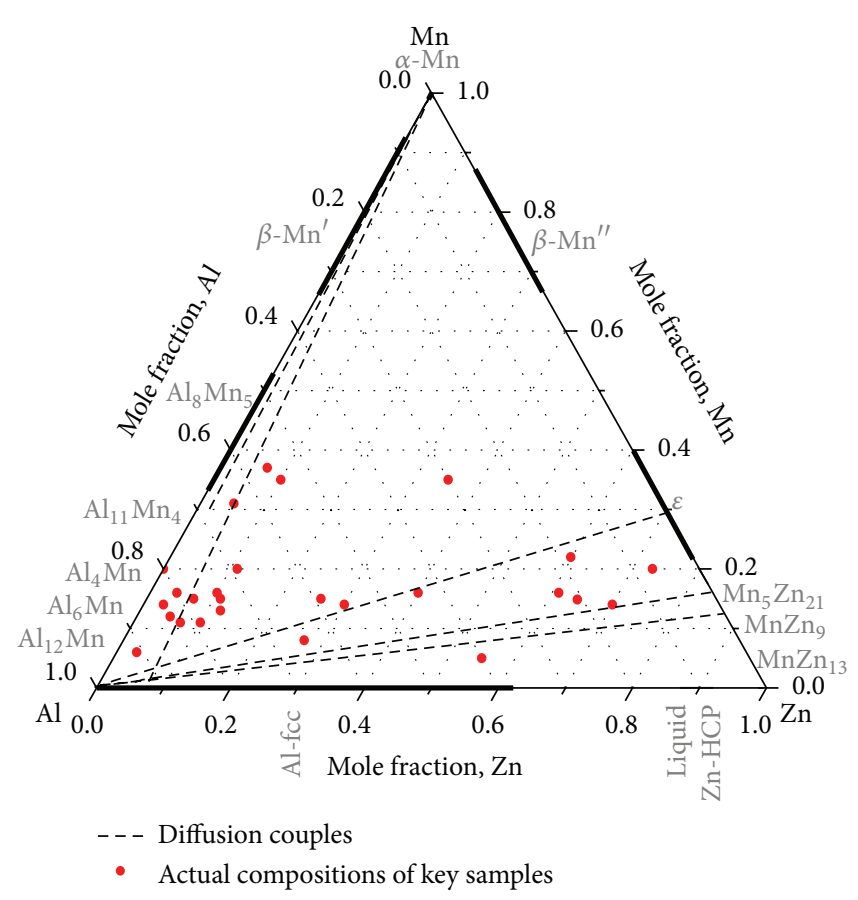

FIGURE 1: Terminal compositions of diffusion couples and actual compositions of key alloys.

Preliminary study was carried out using three diffusion couples DC 1 to 3. Diffusion couples were prepared by grinding down the contacting interfaces using 1200 grit SiC paper and then polished up to $1 \mu \mathrm{m}$ using alcohol-based diamond suspension. $99 \%$ pure ethanol was used as lubricant. The selected end-members were carefully pressed and clamped together using a stainless steel ring, placed in a Ta container, and sealed in a quartz tube under vacuum atmosphere. The encapsulated samples were then annealed at $400^{\circ} \mathrm{C}$ for 4 weeks. After obtaining preliminary results from the first three diffusion couples, two more diffusion couples (DC 4 and 5) and seventeen key alloys (1 to 17) were prepared to obtain the main phase relationships. The composition of the endmembers used in diffusion couples are listed in Table 1. The selection of these end-members was based on preliminary thermodynamic calculations using the models of the binary systems reported by $[6,14,32]$. The probable diffusion paths were expected to cross several phase regions, which could lead to formation of large number of the diffusion layers. The compositions of the selected key alloys and the terminal composition of the diffusion couples are plotted in Figure 1. 
In order to identify the minor inconsistencies, the final study was preceded by preparing another nine key samples (18 to 26). All the key alloys were annealed at $400^{\circ} \mathrm{C}$ for 4 weeks.

The selection of annealing temperature is based on the homogenization time of alloys and their melting temperature. The annealing temperature should be high enough for fast homogenization interdiffusion and kinetics in the alloys. Meanwhile, the annealing temperature should be lower than the melting temperature of the alloys. The lowest eutectic temperature in this system is around $390^{\circ} \mathrm{C}$ in $\mathrm{Zn}$-rich corner. However, this work is focused on Al-alloys and all samples were prepared away from $\mathrm{Zn}$-rich corner. Therefore, $400^{\circ} \mathrm{C}$ was selected in order to have faster interdiffusion and relatively shorter annealing time.

Key alloys and diffusion couples were investigated using electron probe microanalysis (EPMA) and scanning electron microscopy (SEM) equipped with energy dispersive $\mathrm{X}$-ray spectroscopy (EDS). The microstructure and phase composition of the samples were analyzed either by EPMA (JOEL-JXA-8900) or SEM/EDS (HITACHI S-3400N). The difference between EPMA and SEM/EDS results was less than 2 at \% for Mn. This value was obtained by comparing the composition of several samples using both techniques. $\mathrm{X}$-ray diffraction (XRD) was used for phase analysis of the key alloys and for the determination of the solubility limits of the compounds. The XRD patterns were obtained using PANanalytical Xpert Pro powder X-ray diffractometer [33] with a $\mathrm{CuK} \alpha$ radiation at $45 \mathrm{kV}$ and $40 \mathrm{~mA}$. X-ray diffraction analysis of the samples was carried out using X'Pert HighScore Plus Rietveld analysis software [33]. Pearson's crystal database [34] was used to identify the known phases in the Al-Mn-Zn system.

\section{Results and Discussion}

3.1. Experimental Study of Diffusion Couples. Isothermal section of the Al-Mn-Zn ternary system was constructed based on the experimental results of 5 diffusion couples and 26 key samples shown in Figure 1. During the preliminary study, three ternary compounds: $\tau_{1}\left(\mathrm{Al}_{31} \mathrm{Mn}_{8} \mathrm{Zn}_{11}\right), \tau_{2}$ $\left(\mathrm{Al}_{71} \mathrm{Mn}_{16} \mathrm{Zn}_{13}\right)$, and $\tau_{3}\left(\mathrm{Al}_{10} \mathrm{Mn}_{15} \mathrm{Zn}_{75}\right)$ have been found through diffusion couples analysis.

Backscattered electron image of DC $1\left(\mathrm{Al}-\mathrm{Mn}_{11} \mathrm{Zn}_{89}\right)$ is presented in Figure 2(a). Half of the image is colored for better representation of diffusion layers in this diffusion couple. The interdiffusion took place which led to the formation of several diffusion layers. The compositions of the formed phases were determined using EPMA point analysis. EPMA line-scan was used to determine the solubility ranges and phase equilibria among intermetallics. Based on the composition profile obtained by EPMA, as shown in Figure 2(b), the diffusion path was depicted based on the sequence of the phases as $\mathrm{Mn}_{5} \mathrm{Zn}_{21} \rightarrow \mathrm{Al}_{8} \mathrm{Mn}_{5} \rightarrow \mathrm{Al}_{11} \mathrm{Mn}_{4} \rightarrow$ $\tau_{1} \rightarrow$ Al-fcc. New ternary intermetallic compound $\tau_{1}$ has been found in this diffusion couple. $\tau_{1}$ was determined as a compound with the composition of $\mathrm{Al}_{62} \mathrm{Mn}_{16} \mathrm{Zn}_{22}$. As can be seen from Figure 2(b), the three points of EPMA results show no solubility range of $\tau_{1}$. Additional key alloy analysis was consistent with the results of DC $1\left(\mathrm{Al}-\mathrm{Mn}_{11} \mathrm{Zn}_{89}\right)$. This is why this compound is considered as stoichiometric. Figure 2(c) shows the estimated diffusion path of DC 1 (Al$\mathrm{Mn}_{11} \mathrm{Zn}_{89}$ ) plotted on the Al-Mn-Zn Gibbs triangle. Layer number 1 was determined as $\mathrm{Mn}_{5} \mathrm{Zn}_{21}$. The solubility of $\mathrm{Al}$ in $\mathrm{Mn}_{5} \mathrm{Zn}_{21}$ was measured as 5 at $\%$, where $\mathrm{Al}$ atoms substitute $\mathrm{Zn}$ atoms and Mn content remains constant at 16 at\%. Based on the local equilibrium at the $\mathrm{Mn}_{5} \mathrm{Zn}_{21} / \mathrm{Al}_{8} \mathrm{Mn}_{5}$ interface, $\mathrm{Mn}_{5} \mathrm{Zn}_{21}$ is in equilibrium with $\mathrm{Al}_{8} \mathrm{Mn}_{5}$. In layer number 2, $\mathrm{Al}_{8} \mathrm{Mn}_{5}$ solid solution dissolves up to 7 at $\% \mathrm{Zn}$ as shown in Figure 2(b). This homogeneity range was also confirmed

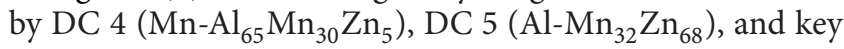
alloys 13-17. The composition of $\mathrm{Al}_{8} \mathrm{Mn}_{5}$ did not vary in $\mathrm{DC} 1$ (Al- $\mathrm{Mn}_{11} \mathrm{Zn}_{89}$ ) because the diffusion path changed direction to form $\mathrm{Al}_{11} \mathrm{Mn}_{4}$ layer. Layer number 3 was determined as $\mathrm{Al}_{11} \mathrm{Mn}_{4}$ with limited ternary solubility of around 2 at $\% \mathrm{Zn}$. This value can be considered negligible, because the estimated error of EPMA measurement is about 2 at \%. Layer number 4 contains two phases; these are $\mathrm{Al}_{11} \mathrm{Mn}_{4}$ and $\tau_{1}$. The results of point analysis indicated that $\mathrm{Al}_{11} \mathrm{Mn}_{4}$ has negligible ternary solubility, and $\tau_{1}$ has the composition of $\mathrm{Al}_{62} \mathrm{Mn}_{16} \mathrm{Zn}_{22}$. Layer number 5 was identified as $\tau_{1}$. Results of line-scan across $\tau_{1}$ layer showed that the composition of $\tau_{1}$ is constant as $\mathrm{Al}_{62} \mathrm{Mn}_{16} \mathrm{Zn}_{22}$. In layer number 6, Al-fcc was in equilibrium with $\tau_{1}$. The solubility of $\mathrm{Zn}$ in Al-fcc was found to reach up to 20 at\%, based on the EPMA line-scan results.

DC $2\left(\mathrm{Mn}-\mathrm{Al}_{94} \mathrm{Zn}_{6}\right)$ was annealed at $400^{\circ} \mathrm{C}$ for two different time periods (15 and 25 days) in order to understand the phase formation kinetics. The annealing time resulted in significant growth of some compounds at the expense of others. This can be clearly seen in Figures 3(a) and 3(b), where the layer thickness of $\mathrm{Al}_{11} \mathrm{Mn}_{4}$ is growing at the expense of $\mathrm{Al}_{4} \mathrm{Mn}$ and $\tau_{2}$. Six layers were observed in this diffusion couple for both annealing times. The sequence of the observed phases is represented as follows: Al-fcc $\rightarrow \tau_{2} \rightarrow \mathrm{Al}_{4} \mathrm{Mn} \rightarrow$ $\mathrm{Al}_{11} \mathrm{Mn}_{4} \rightarrow \mathrm{Al}_{8} \mathrm{Mn}_{5} \rightarrow \beta-\mathrm{Mn}^{\prime} \rightarrow \beta-\mathrm{Mn}^{\prime \prime} \rightarrow \mathrm{Mn}$. The ternary compound $\mathrm{T} 3\left(\mathrm{Al}_{11} \mathrm{Mn}_{3} \mathrm{Zn}_{2}\right)$ reported by [24] was observed in this diffusion couple and is denoted as $\tau_{2}$ in this paper, as shown in Figures $3(\mathrm{a})$ and $3(\mathrm{~b}) . \tau_{2}$ was determined as $\mathrm{Al}_{71} \mathrm{Mn}_{16} \mathrm{Zn}_{13}$, which is close to the composition of $\mathrm{T} 3$ $\left(\mathrm{Al}_{69} \mathrm{Mn}_{19} \mathrm{Zn}_{12}\right)$ as reported by Raynor and Wakeman [24]. In DC $2\left(\mathrm{Mn}-\mathrm{Al}_{94} \mathrm{Zn}_{6}\right)$, finger-like structure morphology can be observed after annealing for 15 days as shown in Figure 3(b). This type of morphology indicates anisotropic diffusion of the three elements in this system. $\mathrm{Al}_{11} \mathrm{Mn}_{4}$ showed higher growth rate compared to other phases in this diffusion couple. This was concluded by comparing the micrographs of DC 2 (Figures 3(a) and 3(b)). Both thicknesses of $\tau_{2}$ and $\mathrm{Al}_{4} \mathrm{Mn}$ decreased after annealing for additional 10 days as shown in Figure 3(b). The $\mathrm{Mn}$ content of $\mathrm{Al}_{4} \mathrm{Mn}$ was found to vary from 18 at $\%$ to 20 at\% after annealing for 15 days, whereas it became constant at 20 at $\% \mathrm{Mn}$ after annealing for 25 days. The solubility of $\mathrm{Zn}$ in $\mathrm{Al}_{4} \mathrm{Mn}$ was measured as 5 at\%. SEM/EDS analysis of DC $2\left(\mathrm{Mn}-\mathrm{Al}_{94} \mathrm{Zn}_{6}\right)$ annealed for 25 days is presented in Figure 3(c). The solubility of $\mathrm{Zn}$ in $\mathrm{Al}_{8} \mathrm{Mn}_{5}$ was measured as 5 at $\%$. The ternary solid solubility of $\beta-\mathrm{Mn}^{\prime}$ was found to be 4 at $\% \mathrm{Zn}$. $\beta$ - $\mathrm{Mn}^{\prime \prime}$ shows limited ternary solubility of 3 at $\% \mathrm{Al}$. 


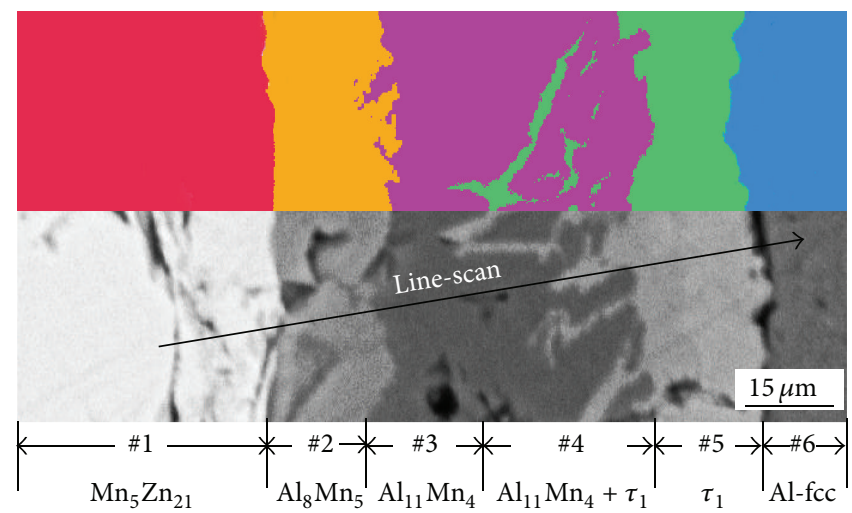

(a)

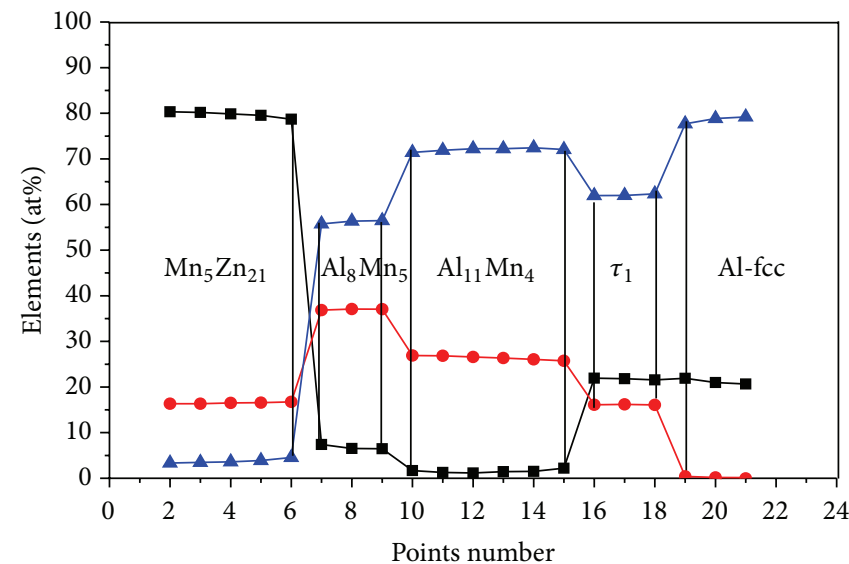

$\because \mathrm{Zn}$
$\rightarrow \mathrm{Mn}$
$\simeq \mathrm{Al}$

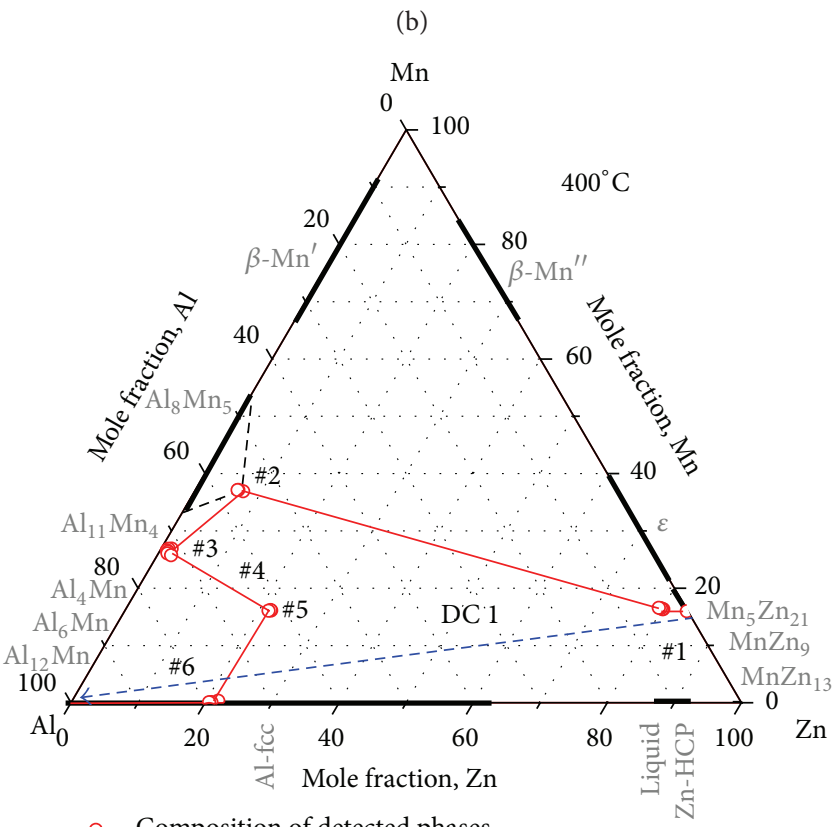

- Composition of detected phases

— Diffusion path

\#1: $\mathrm{Mn}_{5} \mathrm{Zn}_{21}$ layer

$\# 2$ : $\mathrm{Al}_{8} \mathrm{Mn}_{5}$ layer

\#3: $\mathrm{Al}_{11} \mathrm{Mn}_{4}$ layer
$\# 4: \mathrm{Al}_{11} \mathrm{Mn}_{4}+\tau_{1}$ layer

\#5: $\tau_{1}$ layer

\#6: Al-fcc layer

(c)

FIGURE 2: (a) Backscattered electron image of DC $1\left(\mathrm{Al}-\mathrm{Mn}_{11} \mathrm{Zn}_{89}\right)$ and its schematic; (b) composition profile of the line-scan in DC 1 (Al$\left.\mathrm{Mn}_{11} \mathrm{Zn}_{89}\right)$; (c) approximation of diffusion path of DC $1\left(\mathrm{Al}-\mathrm{Mn}_{11} \mathrm{Zn}_{89}\right)$. 


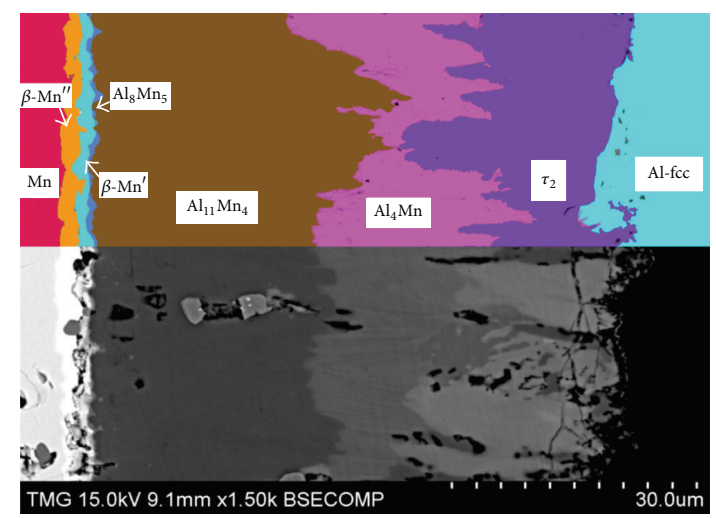

(a)

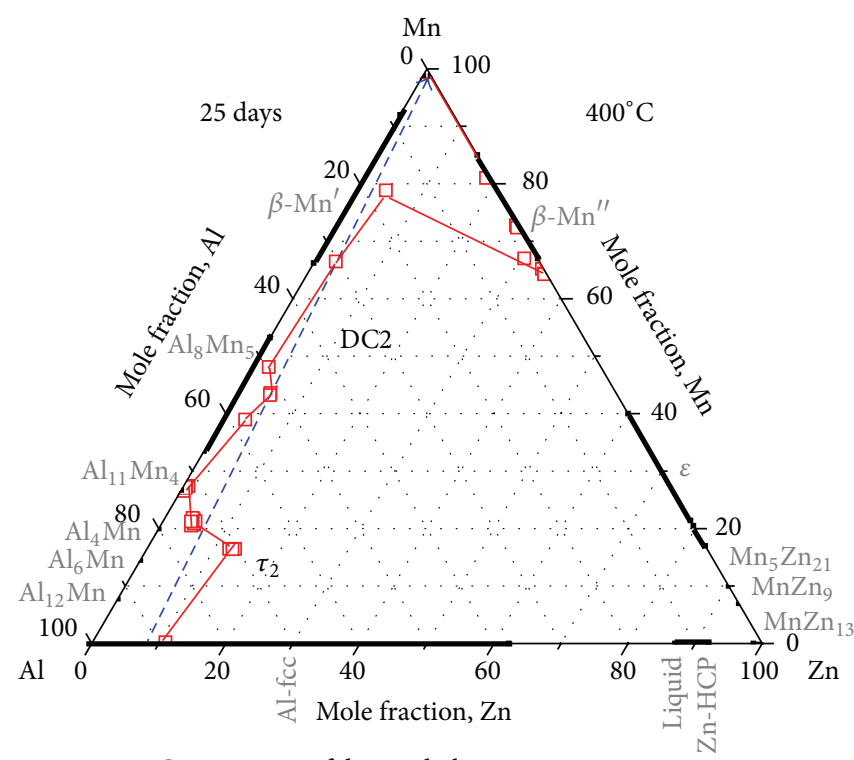

$\square \quad$ Composition of detected phases — Diffusion path

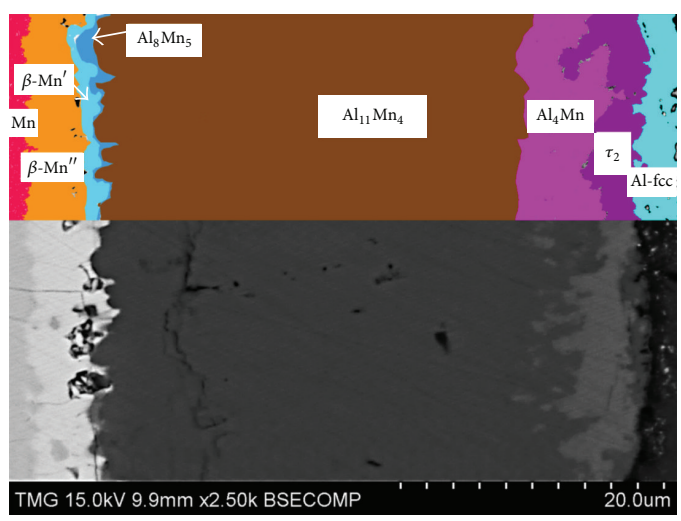

(b)

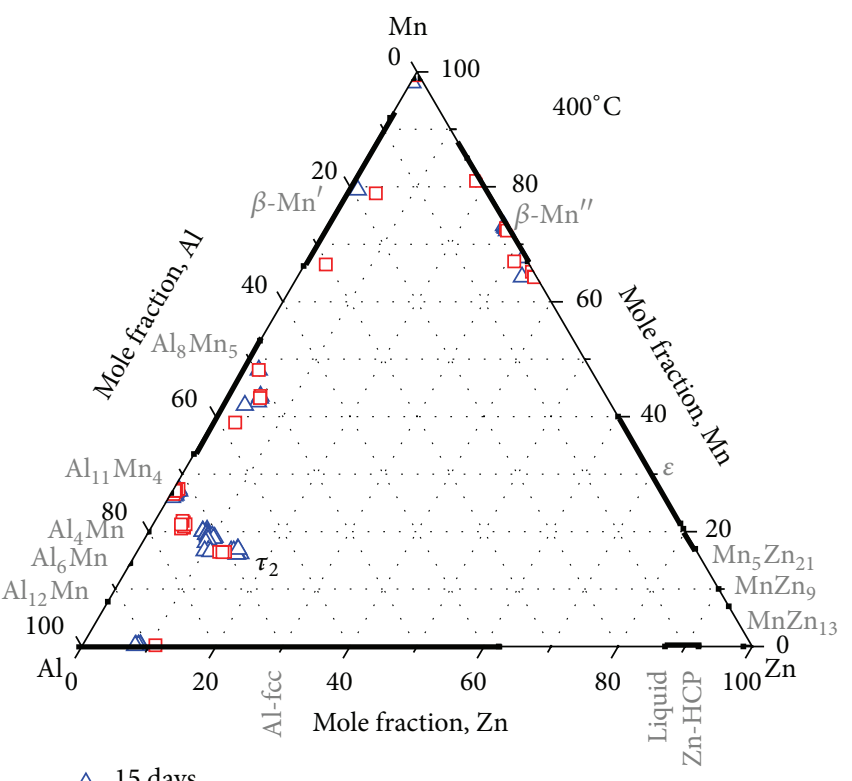

$\triangle 15$ days

$\square \quad 25$ days

(c)

(d)

FIGURE 3: (a) Backscattered electron image of DC $2\left(\mathrm{Mn}-\mathrm{Al}_{94} \mathrm{Zn}_{6}\right)$ annealed at $400^{\circ} \mathrm{C}$ for 15 days along with its schematic; (b) backscattered electron image of DC $2\left(\mathrm{Mn}-\mathrm{Al}_{94} \mathrm{Zn}_{6}\right)$ annealed at $400^{\circ} \mathrm{C}$ for 25 days along with its schematic; (c) diffusion path of $\mathrm{DC} 2\left(\mathrm{Mn}^{-\mathrm{Al}_{94}} \mathrm{Zn}_{6}\right)$ annealed for 25 days; (d) comparisons of DC $2\left(\mathrm{Mn}-\mathrm{Al}_{94} \mathrm{Zn}_{6}\right)$ annealed at 15 days and 25 days.

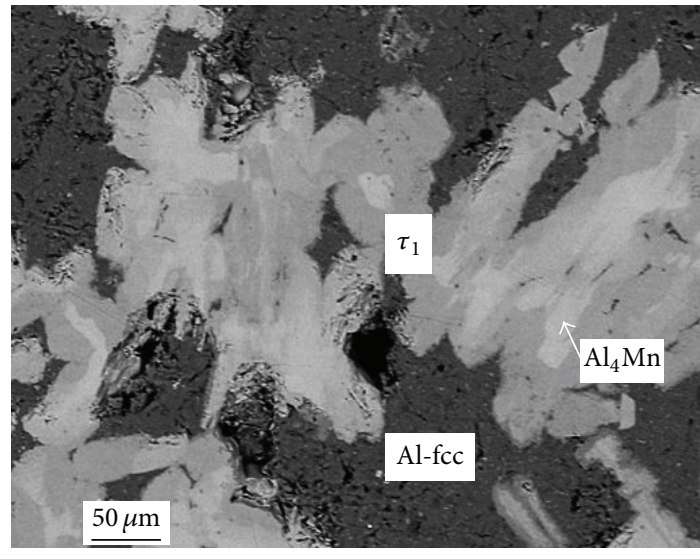

FIGURE 4: Backscattered electron image of sample 1.
DC $3\left(\mathrm{Al}-\mathrm{Mn}_{13} \mathrm{Zn}_{87}\right)$ was studied using the same approach as for DC $1\left(\mathrm{Al}-\mathrm{Mn}_{11} \mathrm{Zn}_{89}\right)$ and DC 2 (Mn$\mathrm{Al}_{94} \mathrm{Zn}_{6}$ ). Four phases have been identified through EPMA analysis: $\tau_{3}, \mathrm{Al}_{8} \mathrm{Mn}_{5}, \mathrm{Al}_{11} \mathrm{Mn}_{4}$, and $\mathrm{Al}$-fcc. EPMA point analysis indicated that the $\tau_{3}$ ternary compound had the composition of $\mathrm{Al}_{10} \mathrm{Mn}_{15} \mathrm{Zn}_{75}$. Other than this, the results of this diffusion couple only confirmed the data obtained from DC 1 and 2. Therefore, the details of DC $3\left(\mathrm{Al}-\mathrm{Mn}_{13} \mathrm{Zn}_{87}\right)$ are not mentioned here to avoid repetition.

3.2. Experimental Study of Key Alloys. Ten key alloys were prepared to verify the formation of phases reported in the literature and confirm the presence of the ternary compounds $\tau_{1}, \tau_{2}$, and $\tau_{3}$ found in this experimental study. The actual 


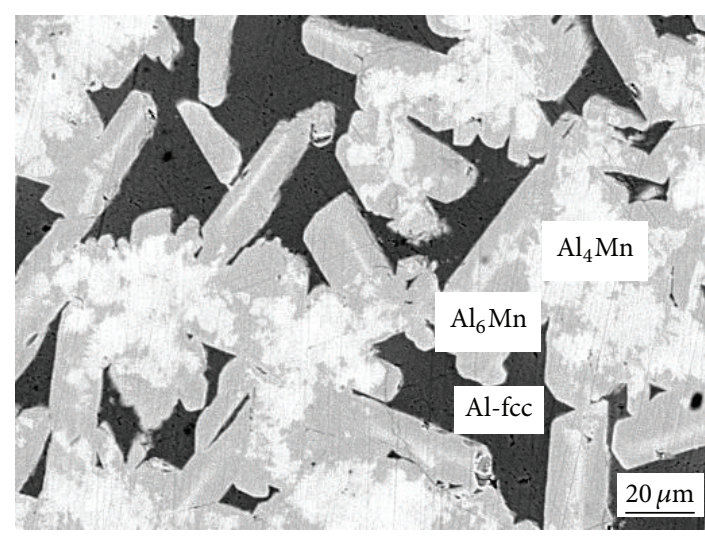

(a)

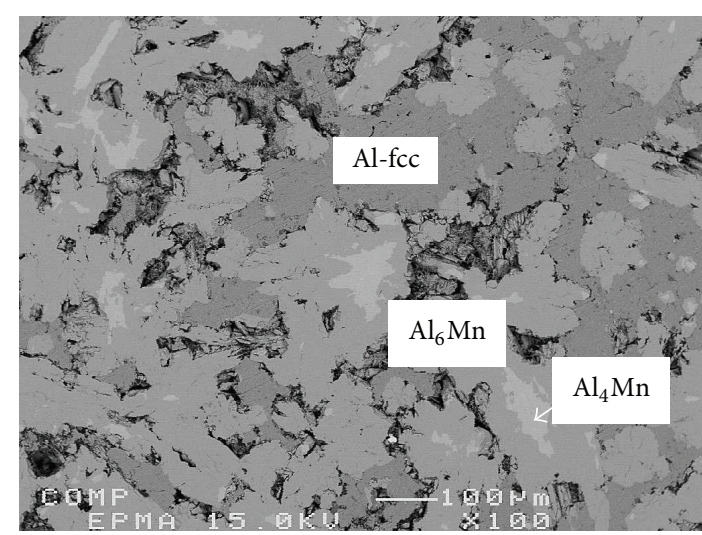

(b)

FIGURE 5: (a) Backscattered electron image of as-cast sample 7; (b) backscattered electron image of annealed sample 7.

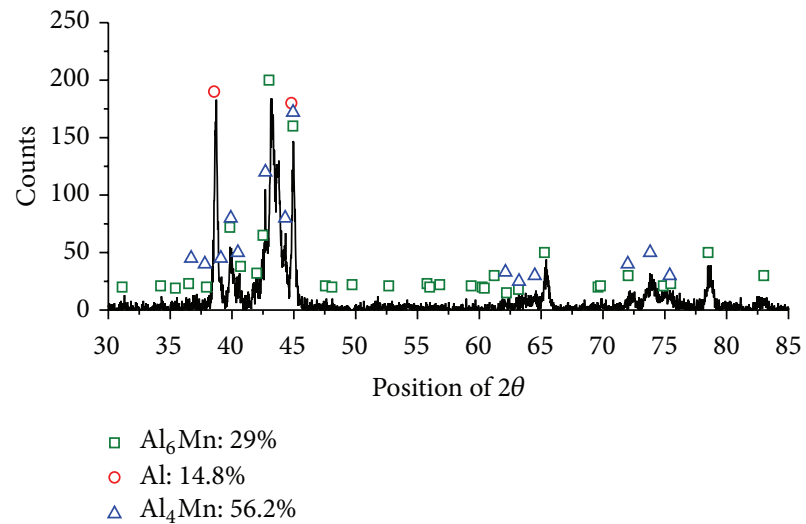

(a)

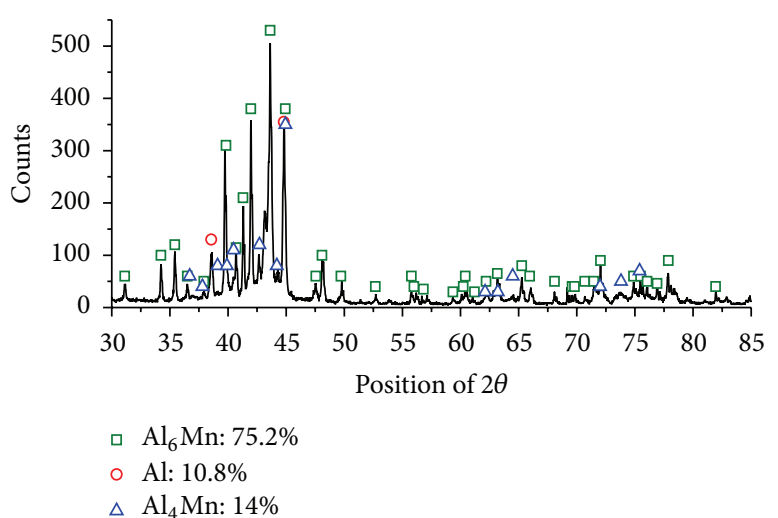

(b)

FiguRE 6: (a) XRD spectrum of as-cast sample 7; (b) XRD spectrum of annealed sample 7.

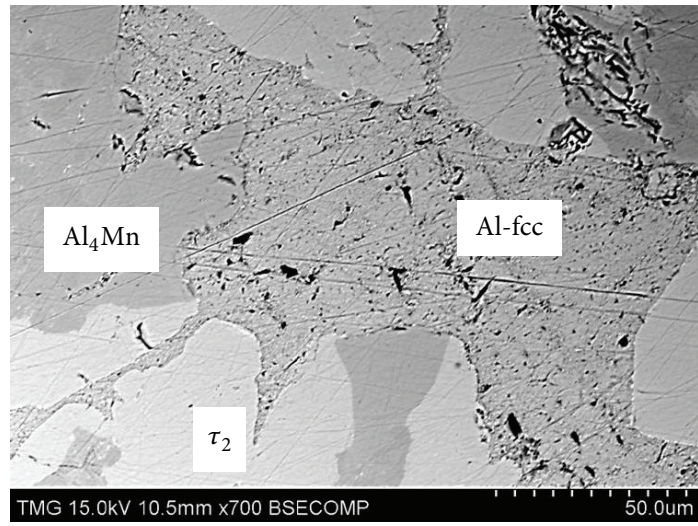

FIGURE 7: Backscattered electron image of sample 3.

composition of these key alloys and the composition of the detected phases are presented in Table 2.

The ternary compounds $\mathrm{T} 1 \quad\left(\mathrm{Al}_{24} \mathrm{Mn}_{5} \mathrm{Zn}\right)$ and $\mathrm{T} 2$ $\left(\mathrm{Al}_{9} \mathrm{Mn}_{2} \mathrm{Zn}\right)$ [24] were not observed in this system at $400^{\circ} \mathrm{C}$.
As shown in Table 2, key alloy 7 was prepared close to the composition of $\mathrm{T} 1$ compound; key alloys 5 and 6 were made close to the composition of $\mathrm{T} 2$ compound. However, $\mathrm{T} 1$ and T2 were not detected. It should be mentioned that Raynor and Wakeman [24] used only as-cast samples in their study and reported compounds could be metastable or high temperature phases. Furthermore, they [24] have used the wet chemical analysis of small quantities of extracted crystals, which may cause errors in phase compositions determination compared to EPMA point analysis used in our work. The existence of $\tau_{1}$ phase was confirmed in sample 1 as a stoichiometric compound with $\mathrm{Al}_{64} \mathrm{Mn}_{15} \mathrm{Zn}_{21}$ composition. The microstructure of this alloy is shown in Figure 4. $\tau_{1}$ formed during a peritectic reaction, which is hard to be terminated during short annealing period. Therefore, the primary phase $\mathrm{Al}_{4} \mathrm{Mn}$ was not decomposed completely even after annealing for 30 days. Similar phenomenon was also observed in key sample 7. Figures 5(a) and 5(b) show the as-cast and annealed microstructures of sample 7. It is clear that $\mathrm{Al}_{4} \mathrm{Mn}$ (the white phase) formed as a primary phase. $\mathrm{Al}_{6} \mathrm{Mn}$ then formed according to the peritectic reaction: $\mathrm{L}+\mathrm{Al}_{4} \mathrm{Mn} \rightarrow \mathrm{Al}_{6} \mathrm{Mn}$. After annealing for 30 days, 
TABLE 2: The actual compositions of the key samples and the detected phases.

\begin{tabular}{|c|c|c|c|c|c|c|c|c|}
\hline \multirow{2}{*}{$\begin{array}{l}\text { Sample } \\
\text { number }\end{array}$} & \multicolumn{3}{|c|}{$\begin{array}{c}\text { Actual composition } \\
\text { identified by ICP (at\%) }\end{array}$} & \multicolumn{2}{|c|}{ Phase identification } & \multicolumn{3}{|c|}{$\begin{array}{l}\text { Composition of } \\
\text { identified phases } \\
\text { by EPMA (at } \%)\end{array}$} \\
\hline & $\mathrm{Al}$ & Mn & $\mathrm{Zn}$ & $\begin{array}{c}\text { By } \\
\text { EPMA }\end{array}$ & $\begin{array}{c}\text { By } \\
\text { XRD }\end{array}$ & $\mathrm{Al}$ & $\mathrm{Mn}$ & $\mathrm{Zn}$ \\
\hline \multirow{3}{*}{1} & \multirow{3}{*}{44} & \multirow{3}{*}{16} & \multirow{3}{*}{40} & $\mathrm{Al}_{4} \mathrm{Mn}$ & $\mathrm{Al}_{4} \mathrm{Mn}$ & 74 & 20 & 6 \\
\hline & & & & $\tau_{1}$ & & 64 & 15 & 21 \\
\hline & & & & Al-fcc & Al-fcc & 55 & 0 & 45 \\
\hline \multirow{3}{*}{2} & \multirow{3}{*}{75} & \multirow{3}{*}{13} & \multirow{3}{*}{12} & $\tau_{2}$ & $\tau_{2}$ & 73 & 15 & 12 \\
\hline & & & & $\mathrm{Al}_{4} \mathrm{Mn}$ & $\mathrm{Al}_{4} \mathrm{Mn}$ & 74 & 20 & 6 \\
\hline & & & & $\mathrm{Al}-\mathrm{fcc}$ & $\mathrm{Al}-\mathrm{fcc}$ & 78 & 0 & 22 \\
\hline \multirow{3}{*}{3} & \multirow{3}{*}{78} & \multirow{3}{*}{15} & \multirow{3}{*}{7} & $\tau_{2}$ & $\tau_{2}$ & 75 & 14 & 11 \\
\hline & & & & $\mathrm{Al}_{4} \mathrm{Mn}$ & $\mathrm{Al}_{4} \mathrm{Mn}$ & 75 & 20 & 5 \\
\hline & & & & $\mathrm{Al}-\mathrm{fcc}$ & $\mathrm{Al}-\mathrm{fcc}$ & 88 & 0 & 12 \\
\hline \multirow{3}{*}{4} & \multirow{3}{*}{79} & \multirow{3}{*}{10} & \multirow{3}{*}{11} & $\tau_{2}$ & $\tau_{2}$ & 72 & 16 & 12 \\
\hline & & & & $\mathrm{Al}_{4} \mathrm{Mn}$ & $\mathrm{Al}_{4} \mathrm{Mn}$ & 76 & 20 & 4 \\
\hline & & & & $\mathrm{Al}-\mathrm{fcc}$ & $\mathrm{Al}-\mathrm{fcc}$ & 79 & 0 & 21 \\
\hline \multirow{3}{*}{5} & & & & $\tau_{2}$ & $\tau_{2}$ & 73 & 15 & 12 \\
\hline & 74 & 16 & 10 & $\mathrm{Al}_{4} \mathrm{Mn}$ & $\mathrm{Al}_{4} \mathrm{Mn}$ & 74 & 20 & 6 \\
\hline & & & & $\mathrm{Al}-\mathrm{fcc}$ & Al-fcc & 75 & 0 & 25 \\
\hline & & & & $\tau_{2}$ & $\tau_{2}$ & 72 & 15 & 13 \\
\hline 6 & 74 & 15 & 11 & $\mathrm{Al}_{4} \mathrm{Mn}$ & $\mathrm{Al}_{4} \mathrm{Mn}$ & 74 & 20 & 6 \\
\hline & & & & Al-fcc & Al-fcc & 80 & 0 & 20 \\
\hline & & & & $\mathrm{Al}_{6} \mathrm{Mn}$ & $\mathrm{Al}_{6} \mathrm{Mn}$ & 86 & 14 & 0 \\
\hline 7 & 84 & 12 & 4 & $\mathrm{Al}_{4} \mathrm{Mn}$ & $\mathrm{Al}_{4} \mathrm{Mn}$ & 75 & 20 & 5 \\
\hline & & & & $\mathrm{Al}-\mathrm{fcc}$ & $\mathrm{Al}-\mathrm{fcc}$ & 95 & 0 & 5 \\
\hline & & & & $\mathrm{Al}_{12} \mathrm{Mn}$ & & 92 & 8 & 0 \\
\hline 8 & 82 & 11 & 7 & $\mathrm{Al}_{6} \mathrm{Mn}$ & & 83 & 15 & 2 \\
\hline & & & & Al-fcc & & 96 & 0 & 4 \\
\hline & & & & $\tau_{3}$ & & 12 & 11 & 77 \\
\hline 9 & 21 & 14 & 65 & $\mathrm{Al}_{11} \mathrm{Mn}_{4}$ & $\mathrm{Al}_{11} \mathrm{Mn}_{4}$ & 70 & 26 & 3 \\
\hline & & & & $\mathrm{Al}_{8} \mathrm{Mn}_{5}$ & $\mathrm{Al}_{8} \mathrm{Mn}_{5}$ & 56 & 37 & 7 \\
\hline & & & & $\tau_{3}$ & & 12 & 11 & 77 \\
\hline 10 & 16 & 14 & 70 & $\tau_{4}$ & & 23 & 16 & 61 \\
\hline & & & & $\mathrm{Al}_{11} \mathrm{Mn}_{4}$ & $\mathrm{Al}_{11} \mathrm{Mn}_{4}$ & 71 & 25 & 4 \\
\hline & & & & $\tau_{3}$ & & 13 & 13 & 74 \\
\hline 11 & 23 & 16 & 61 & $\tau_{4}$ & & 25 & 18 & 57 \\
\hline & & & & $\mathrm{Al}_{11} \mathrm{Mn}_{4}$ & $\mathrm{Al}_{11} \mathrm{Mn}_{4}$ & 69 & 27 & 4 \\
\hline & & & & $\mathrm{Al}_{8} \mathrm{Mn}_{5}$ & $\mathrm{Al}_{8} \mathrm{Mn}_{5}$ & 55 & 36 & 9 \\
\hline & & & & $\mathrm{Al}_{11} \mathrm{Mn}_{4}$ & $\mathrm{Al}_{11} \mathrm{Mn}_{4}$ & 70 & 26 & 4 \\
\hline 12 & 17 & 15 & 68 & $\tau_{3}$ & & 13 & 11 & 76 \\
\hline & & & & $\tau_{4}$ & & 23 & 16 & 61 \\
\hline 13 & 18 & 22 & 60 & $\tau_{3}$ & & 10 & 15 & 75 \\
\hline & 10 & 22 & 00 & $\mathrm{Al}_{8} \mathrm{Mn}_{5}$ & $\mathrm{Al}_{8} \mathrm{Mn}_{5}$ & $52-57$ & $33-37$ & $10-11$ \\
\hline 14 & 64 & 31 & 5 & $\mathrm{Al}_{11} \mathrm{Mn}_{4}$ & $\mathrm{Al}_{11} \mathrm{Mn}_{4}$ & 70 & 26 & 4 \\
\hline 14 & 04 & 31 & 3 & $\mathrm{Al}_{8} \mathrm{Mn}_{5}$ & $\mathrm{Al}_{8} \mathrm{Mn}_{5}$ & 55 & 34 & 10 \\
\hline 15 & 56 & 37 & 7 & $\mathrm{Al}_{8} \mathrm{Mn}_{5}$ & $\mathrm{Al}_{8} \mathrm{Mn}_{5}$ & 57 & 39 & 4 \\
\hline 16 & 55 & 35 & 10 & $\mathrm{Al}_{11} \mathrm{Mn}_{4}$ & $\mathrm{Al}_{11} \mathrm{Mn}_{4}$ & 70 & 27 & 3 \\
\hline & & & & $\mathrm{Al}_{8} \mathrm{Mn}_{5}$ & $\mathrm{Al}_{8} \mathrm{Mn}_{5}$ & 57 & 34 & 9 \\
\hline 17 & 30 & 35 & 35 & $\mathrm{Al}_{8} \mathrm{Mn}_{5}$ & & 54 & 38 & 8 \\
\hline 17 & 0 & (3) & (1) & $\varepsilon$ & & 74 & 22 & 4 \\
\hline
\end{tabular}




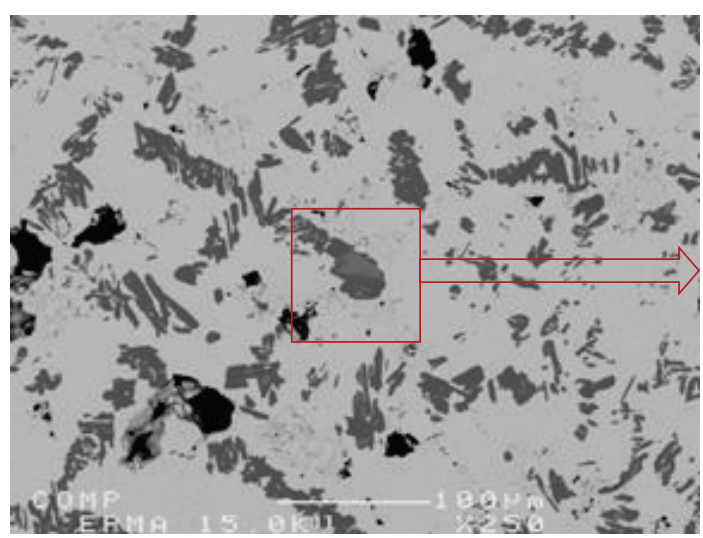

(a)

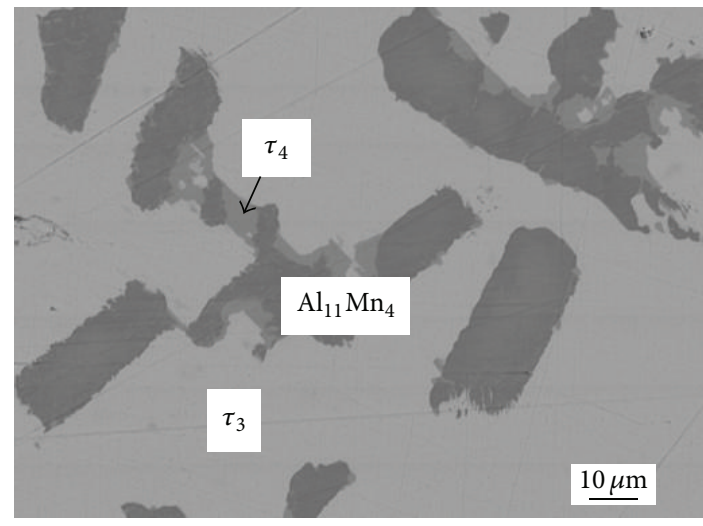

(c)

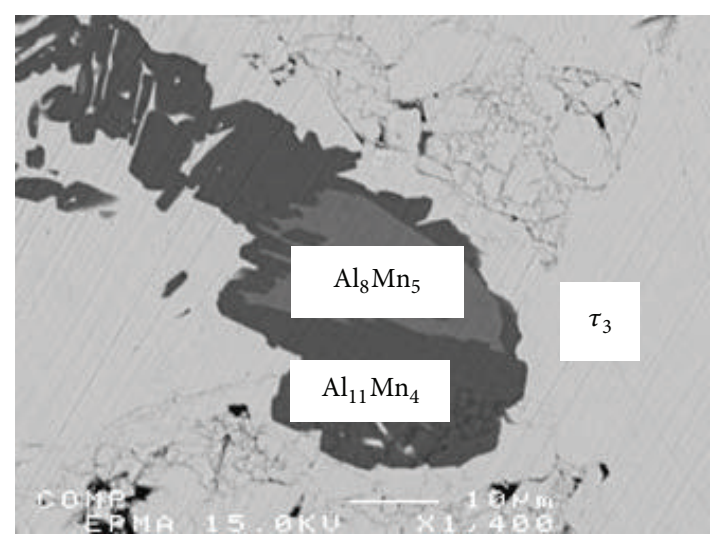

(b)

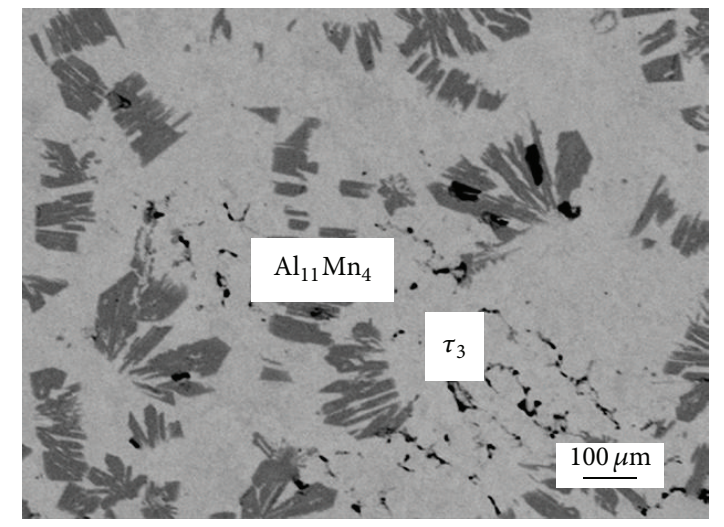

(d)

Figure 8: (a) Backscattered electron image of annealed sample 9 at $400^{\circ} \mathrm{C}$ for 30 days; (b) magnified area of sample 9; (c) backscattered electron image of sample 10 annealed at $400^{\circ} \mathrm{C}$ for 25 days; (d) backscattered electron image of sample 10 annealed at $400^{\circ} \mathrm{C}$ for 40 days.

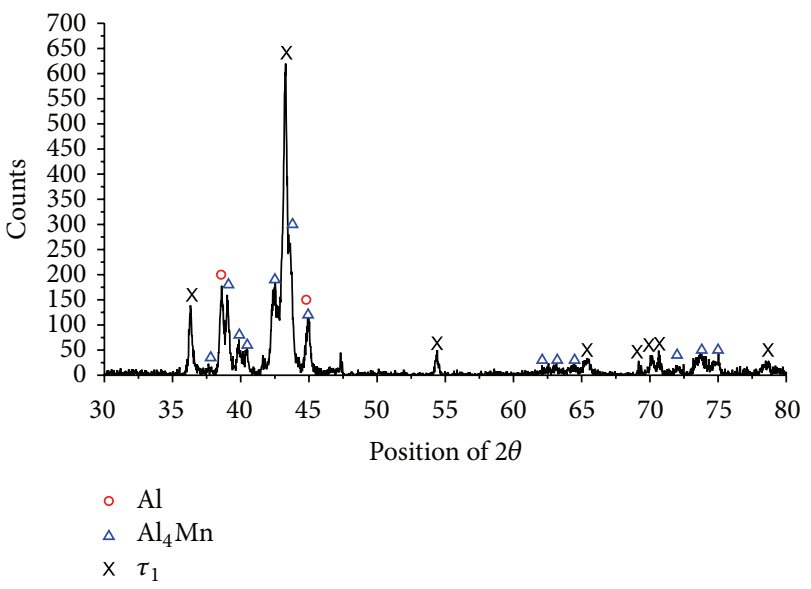

FIGURE 9: XRD spectrum of annealed sample 1.

the amount of $\mathrm{Al}_{4} \mathrm{Mn}$ decreased and decomposed to $\mathrm{Al}_{6} \mathrm{Mn}$. The microstructure of annealed sample 7 is shown in Figure 5(b). Using XRD analysis, the weight fraction of $\mathrm{Al}_{4} \mathrm{Mn}$ and $\mathrm{Al}_{6} \mathrm{Mn}$ in the as-cast sample was measured as $56.2 \%$ and $29 \%$, respectively, as shown in Figure 6(a).
The amount of $\mathrm{Al}_{4} \mathrm{Mn}$ and $\mathrm{Al}_{6} \mathrm{Mn}$ changed dramatically after annealing for 30 days to become $14 \%$ and $82.2 \%$ as demonstrated in Figure 6(b). This variation indicates peritectic decomposition upon annealing. Due to the natural sluggish kinetics of peritectic reaction, the transformation of $\mathrm{Al}_{4} \mathrm{Mn}$ to $\mathrm{Al}_{6} \mathrm{Mn}$ requires very long time.

The formation of $\tau_{2}$ was confirmed after analysis of key alloys 2 to 6 . The microstructure of sample 3 is shown in Figure 7. EPMA results indicated that $\tau_{2}$ is a stoichiometric compound with $\mathrm{Al}_{71} \mathrm{Mn}_{16} \mathrm{Zn}_{13}$ composition. It has been observed that the $\mathrm{Mn}$ content of $\mathrm{Al}_{4} \mathrm{Mn}$ varies in the range of $18-21$ at $\%$, which could be owing to the $\mathrm{Zn}$ substitution. The dissolved $\mathrm{Zn}$ in $\mathrm{Al}_{4} \mathrm{Mn}$ was found to reach up to 6 at\%. Substitution of third element could lead to the small variations of compositions. On the other hand, these Mn content deviations could be due to the fact that $\mathrm{Al}_{4} \mathrm{Mn}$ forms quasicrystals. The structure of quasicrystal may change under different solidification conditions [27]. Schaefer et al. [27] mentioned that $\mathrm{Al}_{4} \mathrm{Mn}$ formed icosahedral or decagonal quasicrystals and structural changes in solid solutions could affect the compositions. They [27] observed that composition of ternary quasicrystals most likely fall in the range of $18-22$ at\% $\mathrm{Mn}$, which was close to the composition region of the stable $\mu$ $\mathrm{Al}_{4} \mathrm{Mn}$ phase. The composition of reported $\mathrm{T} 1$ is close to 


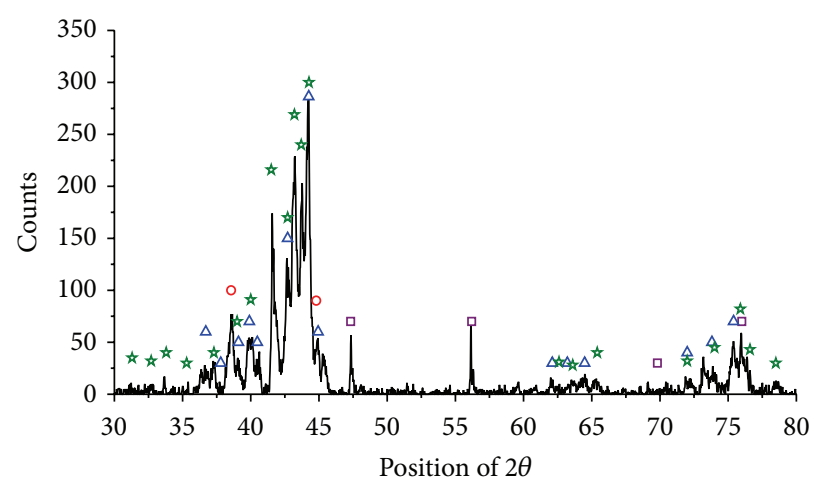

(a)

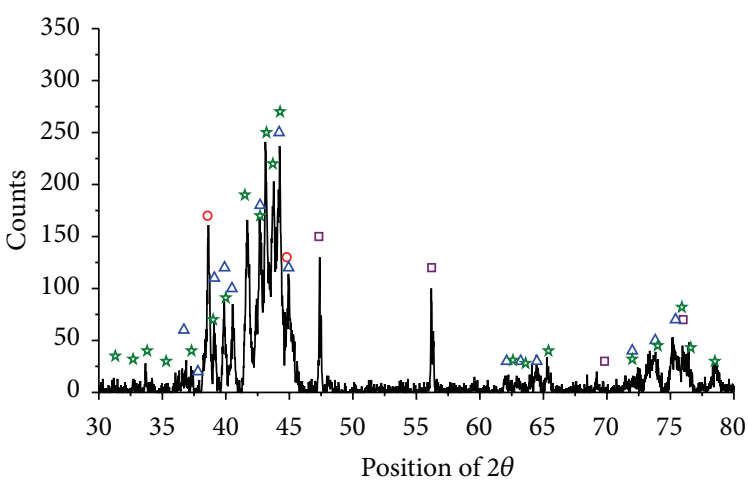

(b)

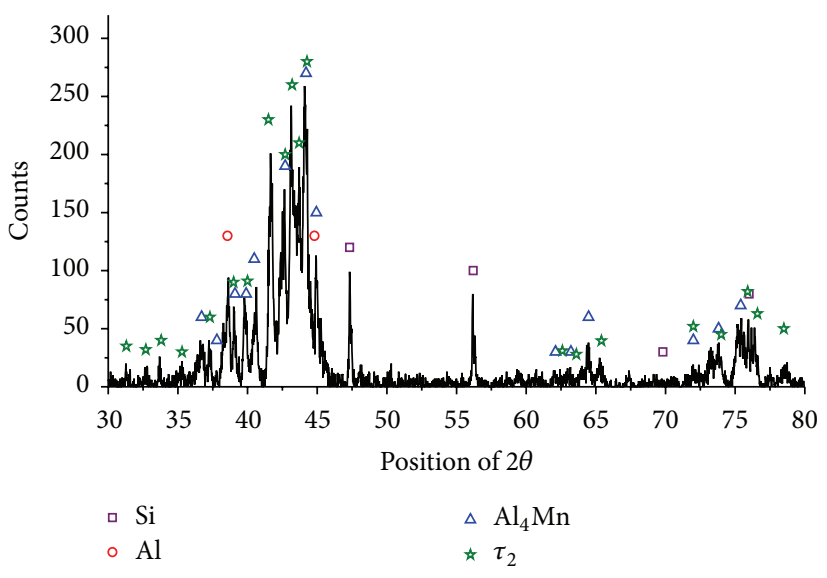

(c)

FIGURE 10: (a) XRD spectrum of annealed sample 2; (b) XRD spectrum of annealed sample 3; (c) XRD spectrum of annealed sample 5.

the homogeneity range of $\mathrm{Al}_{4} \mathrm{Mn}$, which indicated that $\mathrm{T} 1$ might be a quasicrystal of $\mathrm{Al}_{4} \mathrm{Mn}$ with extended $\mathrm{Zn}$ solubility.

$\tau_{3}$ was observed in DC $3\left(\mathrm{Al}-\mathrm{Mn}_{13} \mathrm{Zn}_{87}\right)$ and the composition was primarily determined as $\mathrm{Al}_{10} \mathrm{Mn}_{15} \mathrm{Zn}_{75}$. Several key alloys were prepared to study this new compound. The actual compositions of these samples and the compositions of the detected phases are listed in Table 2 . The $\tau_{3}$ phase has a complex homogeneity range: $9-13$ at $\% \mathrm{Al}, 11-15$ at $\% \mathrm{Mn}$, and $75-77$ at $\% \mathrm{Zn}$, as was determined by the analysis of DC $3\left(\mathrm{Al}-\mathrm{Mn}_{13} \mathrm{Zn}_{87}\right)$ and key samples 9 to 13 . Sample 9 is an example of these findings as shown in Figures $8(\mathrm{a})$ and $8(\mathrm{~b})$. The sample contains residuals of the primary $\mathrm{Al}_{8} \mathrm{Mn}_{5}$ phase that decomposes according to the peritectic reaction: $\mathrm{L}+$ $\mathrm{Al}_{8} \mathrm{Mn}_{5} \rightarrow \mathrm{Al}_{11} \mathrm{Mn}_{4}$. The decomposition of $\mathrm{Al}_{8} \mathrm{Mn}_{5}$ was not complete due to the slow kinetics of the peritectic reaction. $\tau_{3}$ phase formed a matrix in this alloy.

The homogeneity ranges of the binary compounds were determined using EPMA. From the EPMA results, $\mathrm{Al}_{11} \mathrm{Mn}_{4}$ exhibited ternary solubility reaching up to 4 at $\% \mathrm{Zn}$. $\mathrm{Al}_{4} \mathrm{Mn}$ had the maximum ternary solubility of 6 at $\% \mathrm{Zn}$. The dissolved $\mathrm{Zn}$ in $\mathrm{Al}-\mathrm{fcc}$ was found to reach up to 45 at\%. Ternary homogeneity range of $\mathrm{Al}_{8} \mathrm{Mn}_{5}$ has been determined by EPMA as 11 at $\% \mathrm{Zn}$. These observations also confirmed the results which were inferred from DC $4\left(\mathrm{Mn}-\mathrm{Al}_{65} \mathrm{Mn}_{30} \mathrm{Zn}_{5}\right)$.

Additionally, another ternary phase $\tau_{4}$ was found in this ternary system. The composition of this phase is in the region around $\mathrm{Al}_{23} \mathrm{Mn}_{16} \mathrm{Zn}_{61}$. However, $\tau_{4}$ is found to be metastable. As shown in Figure 8(c), three phases $\mathrm{Al}_{11} \mathrm{Mn}_{4}$, $\tau_{3}$, and $\tau_{4}$ were found in sample 12 to be annealed at $400^{\circ} \mathrm{C}$ for 25 days. After prolonged annealing for another 15 days, $\tau_{4}$ decomposed to provide more $\tau_{3}$ and $\mathrm{Al}_{11} \mathrm{Mn}_{4}$.

In order to verify the observations of the ternary compounds, key alloys were studied using XRD. The XRD patterns of sample 1 are illustrated in Figure 9. Al-fcc and $\mathrm{Al}_{4} \mathrm{Mn}$ are positively identified in the XRD pattern. Besides, there are several peaks which do not belong to any of the known binary phases in the system. Based on the results of phase identifications, those peaks could correspond to $\tau_{1}$. Because of the lack of the reported prototype of $\tau_{1}$, the peaks which belong to $\tau_{1}$ were hard to separate, due to the several overlapping peaks in the XRD pattern of this sample. Thus, the crystal structure of this compound could not be determined in the current study. However, the peaks which could belong to $\tau_{1}$ have been labeled as shown in Figure 9 .

T3 phase reported by [24], denoted as $\tau_{2}$ in the current study, was confirmed through XRD analysis. Three XRD spectra of sample 2, 3, and 5 were used for this purpose. As shown in Figure 10, the XRD patterns of the three samples are similar. From $2 \theta$ position $40^{\circ}$ to $45^{\circ}$, hump-like patterns can be observed due to peaks overlapping. This is because $\mathrm{Al}_{4} \mathrm{Mn}$ has very complex crystal structure and has around 550 atoms in a giant unit cell [34]. During the X-ray scanning 


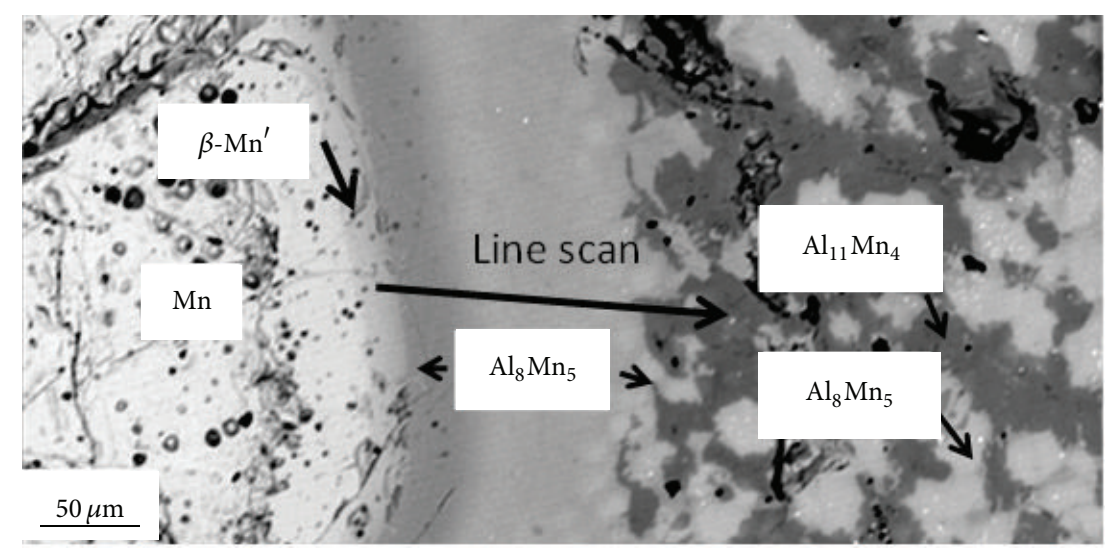

(a)

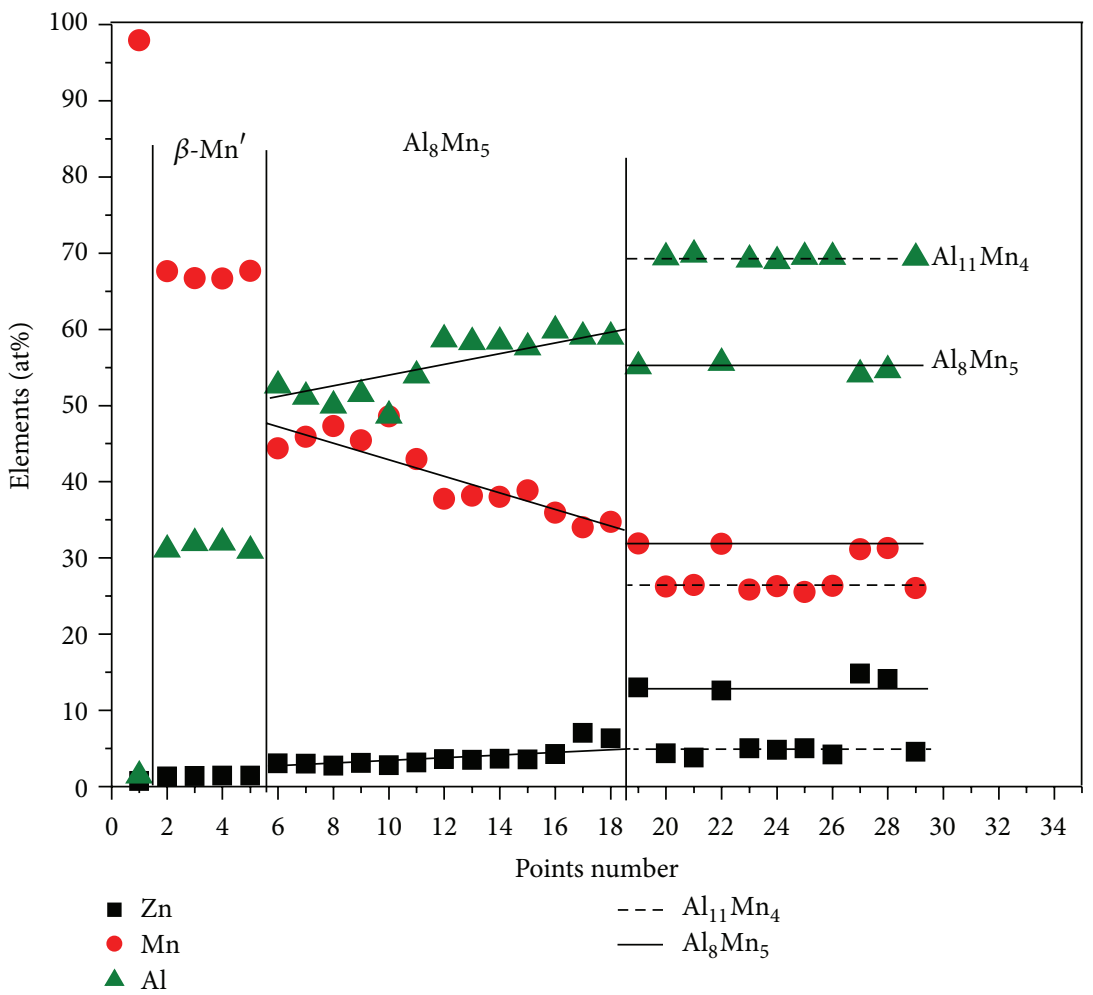

(b)

FIGURE 11: (a) Backscattered electron image of diffusion couple DC 4 (Mn- $\left.\mathrm{Al}_{65} \mathrm{Mn}_{30} \mathrm{Zn}_{5}\right)$; (b) composition profile of line-scan in diffusion couple DC $4\left(\mathrm{Mn}-\mathrm{Al}_{65} \mathrm{Mn}_{30} \mathrm{Zn}_{5}\right)$.

process, the diffracted spectra of $\mathrm{Al}_{4} \mathrm{Mn}$ were overlapping with other peaks at numerous positions and generate these overlapped patterns. Using the crystallographic entry of T3 from Pearson's database [34], T3 was positively identified among XRD analysis. Along with $\mathrm{Al}-\mathrm{fcc}$ and $\mathrm{Al}_{4} \mathrm{Mn}$, the triangulation among those three phases was established.

XRD analysis of ternary compound $\tau_{3}$ has similar issues to $\tau_{1}$ as elucidated above. Unfortunately too many peaks were overlapping in a multiphase alloy and a single-phase sample representing $\tau_{3}$ was not possible to prepare. Therefore, the crystal structure of this compound has not been determined either.

\subsection{Description of Ternary Solid Solutions}

3.3.1. Homogeneity Range of $A l_{8} M n_{5}$ and $A l_{11} M n_{4} \cdot \mathrm{Al}_{8} \mathrm{Mn}_{5}$ has wide homogeneity range in Al-Mn binary system. However, it is difficult to estimate how much of $\mathrm{Zn}$ dissolved in this compound from the results of DC $2\left(\mathrm{Mn}-\mathrm{Al}_{94} \mathrm{Zn}_{6}\right)$. 


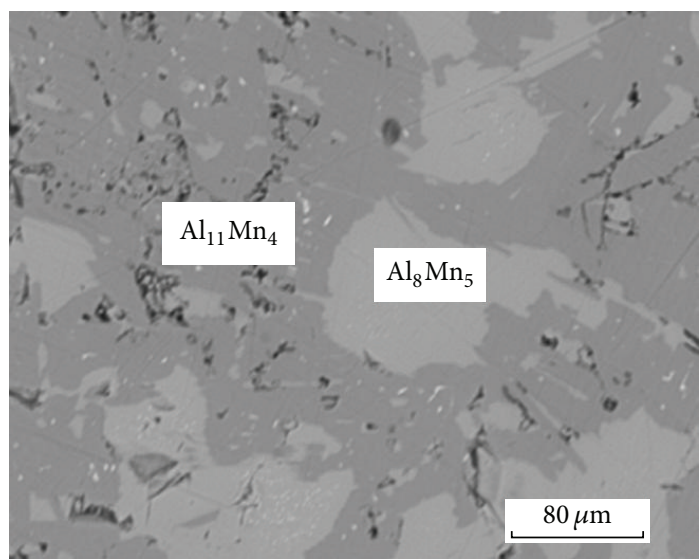

(a)

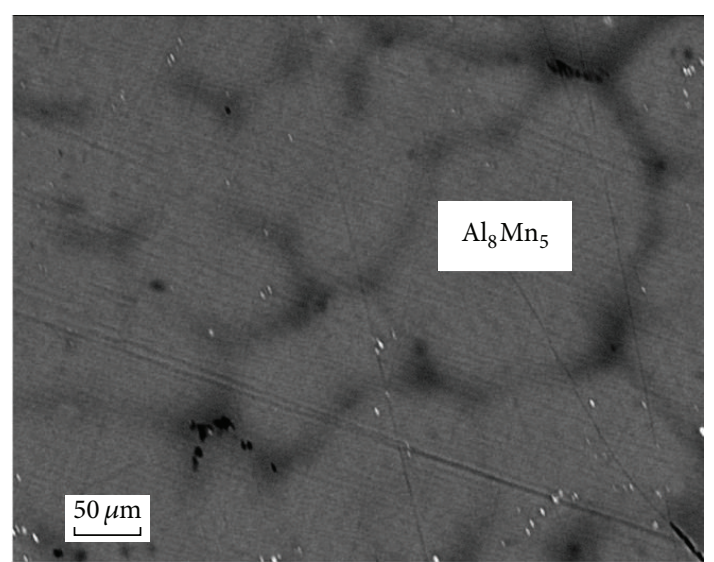

(b)

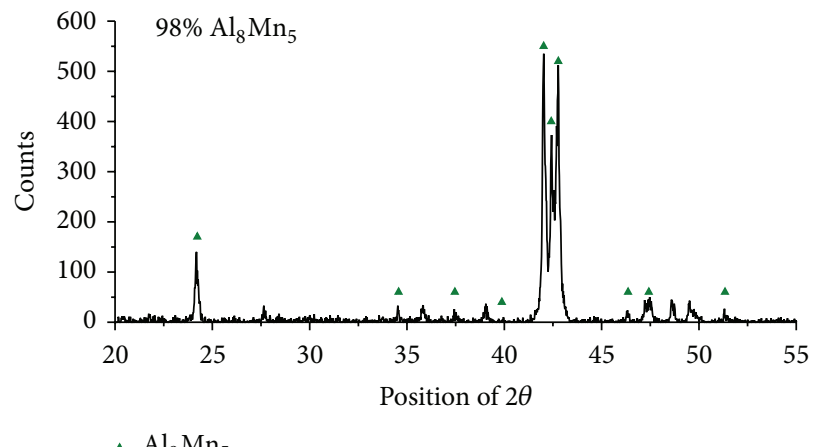

(c)

FIGURE 12: (a) Backscattered electron image of sample 14; (b) backscattered electron image of sample 15; (c) XRD spectrum of sample 15.

Thus, DC $4\left(\mathrm{Mn}^{-\mathrm{Al}_{65}} \mathrm{Mn}_{30} \mathrm{Zn}_{5}\right)$ was prepared in order to determine the homogeneity range of $\mathrm{Al}_{8} \mathrm{Mn}_{5}$ in this ternary system. Because $\mathrm{Al}_{11} \mathrm{Mn}_{4}$ has higher growth rate, one end member of DC $4\left(\mathrm{Mn}-\mathrm{Al}_{65} \mathrm{Mn}_{30} \mathrm{Zn}_{5}\right)$ has been selected near the $\mathrm{Al}_{8} \mathrm{Mn}_{5}$ region to increase the atomic exchange between $\mathrm{Al}$ and $\mathrm{Mn}$. From the backscattered electron image of DC $4\left(\mathrm{Mn}-\mathrm{Al}_{65} \mathrm{Mn}_{30} \mathrm{Zn}_{5}\right.$ ) shown in Figure 11(a), $\mathrm{Al}_{8} \mathrm{Mn}_{5}$ formed a thick layer and the color changed along with decreasing Mn content which suggests the presence of a homogeneity range. Line-scan, shown in Figure 11(b), was carried out to determine the homogeneity range of $\mathrm{Al}_{8} \mathrm{Mn}_{5}$. In the $\mathrm{Al}_{11} \mathrm{Mn}_{4}+\mathrm{Al}_{8} \mathrm{Mn}_{5}$ two-phase region, dotted lines denote the concentrations of elements in $\mathrm{Al}_{11} \mathrm{Mn}_{4}$ and solid lines represent the concentrations of elements in $\mathrm{Al}_{8} \mathrm{Mn}_{5}$. The SEM/EDS analysis showed that $\mathrm{Al}_{8} \mathrm{Mn}_{5}$ has ternary solubility of 9 at $\% \mathrm{Zn}$ and $\mathrm{Al}_{11} \mathrm{Mn}_{4}$ has maximum ternary solubility of 4 at $\% \mathrm{Zn}$. Al concentration in $\mathrm{Al}_{8} \mathrm{Mn}_{5}$ layer varied from 49 at $\%$ to 58 at $\%$.

$\mathrm{Al}_{11} \mathrm{Mn}_{4}$ and $\mathrm{Al}_{8} \mathrm{Mn}_{5}$ showed extended ternary solubility in this system at $400^{\circ} \mathrm{C}$. In order to confirm the results obtained from previous diffusion couples, four key alloys (14 to 17) were prepared. The composition and phase identification of these key samples are summarized in Table 2. The phase relations obtained from EPMA showed great consistency with the XRD results. Backscattered electron image of sample 14 is shown in Figure 12(a). From EPMA point analysis, $\mathrm{Al}_{11} \mathrm{Mn}_{4}$ has a ternary solubility of about 4 at $\%$ $\mathrm{Zn}$ and $\mathrm{Al}_{8} \mathrm{Mn}_{5}$ has a maximum ternary solubility of 10 at $\%$ $\mathrm{Zn}$. These results were consistent with the previous EPMA observation of samples 9 and 11. Figure 12(b) shows that sample 15 contains mainly $\mathrm{Al}_{8} \mathrm{Mn}_{5}$ whose ternary solubility was measured around 4 at $\% \mathrm{Zn}$. The XRD analysis also confirmed that $\mathrm{Al}_{8} \mathrm{Mn}_{5}$ is dominating in sample 15 as shown in Figure 12(c). There are a few unlabeled small peaks indicating the presence of $\mathrm{Al}_{11} \mathrm{Mn}_{4}$ traces which could not be identified in the current study, because of their low intensity.

3.3.2. Single Region of $\varepsilon$ Phase. Controversy on whether $\varepsilon$ has three-phase separations reported in the assessment of Okamoto and Tanner [15] is still not resolved. In the current study, one end-member of DC $5\left(\mathrm{Al}-\mathrm{Mn}_{32} \mathrm{Zn}_{68}\right)$ has a composition in the $\varepsilon$-phase region. EPMA line-scan indicated that $\varepsilon$-phase has continuous binary solubility ranges reaching from $\mathrm{Mn}_{32} \mathrm{Zn}_{68}$ to $\mathrm{Mn}_{40} \mathrm{Zn}_{60}$ at $400^{\circ} \mathrm{C}$. This finding also corresponds to the $\mathrm{Mn}-\mathrm{Zn}$ binary system which was reported by $[32,35]$. The backscattered electron image of DC $5\left(\mathrm{Al}-\mathrm{Mn}_{32} \mathrm{Zn}_{68}\right)$ is presented in Figure 13. Five phases have been identified: $\varepsilon$, Al-rich $\beta-\mathrm{Mn}^{\prime}, \mathrm{Al}_{8} \mathrm{Mn}_{5}, \mathrm{Al}_{11} \mathrm{Mn}_{4}$, and $\mathrm{Al}$ $\mathrm{fcc}$. In the current experimental investigation, the maximum solubility of $\mathrm{Zn}$ in $\beta-\mathrm{Mn}^{\prime}$ was measured as 4 at $\%$. Single $\varepsilon$ phase region with the $\mathrm{Mn}$ content from 32 to 40 at\% was 


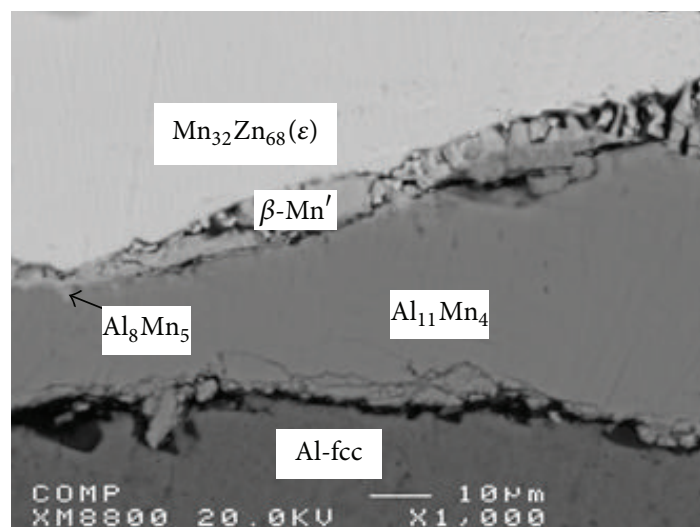

FIGURE 13: Backscattered electron image of DC $5\left(\mathrm{Al}-\mathrm{Mn}_{32} \mathrm{Zn}_{68}\right)$.

observed at $400^{\circ} \mathrm{C}$ and nothing indicated the presence of phase separation in this composition range. From the results of sample $17\left(\mathrm{Al}_{30} \mathrm{Mn}_{35} \mathrm{Zn}_{35}\right)$, $\varepsilon$-phase was found to have limited ternary solubility of 4 at $\% \mathrm{Al}$.

3.4. Isothermal Section of Al-Mn-Zn System at $400^{\circ} \mathrm{C}$. Combining the results which were obtained from the diffusion couples with those obtained from the key alloys, the Al-Mn$\mathrm{Zn}$ isothermal section at $400^{\circ} \mathrm{C}$ was constructed and presented in Figure 14. Solid lines represent the experimentally verified phase boundaries and ternary solubility of binary phases. Dotted lines are the estimated phase relationships which were not confirmed in the current study. They were constructed based on the Gibbs phase rule [36] and Schreinemaker's rule [37]. Grey, blue, and green areas indicate the single, two-phase, and three-phase regions separately, as shown in Figure 14.

\section{Conclusion}

The $\mathrm{Al}-\mathrm{Mn}-\mathrm{Zn}$ isothermal section at $400^{\circ} \mathrm{C}$ was constructed based on the current experimental results of diffusion couple technique and selected key alloys. Phase relationships and solubility limits have been determined for the ternary and binary compounds. The previously reported ternary compound T3 was confirmed in the current study and is denoted as $\tau_{2}$ in this paper. Two new ternary compounds: $\tau_{1}$ and $\tau_{3}$ have been found in this system at $400^{\circ} \mathrm{C}$. $\tau_{1}$ does not show significant solubility ranges and is considered stoichiometric. $\tau_{3}$ is a solid solution with a narrow homogeneity range. The formulae of the three Al-Mn-Zn ternary intermetallic compounds are $\tau_{1}: \mathrm{Al}_{31} \mathrm{Mn}_{8} \mathrm{Zn}_{11}, \tau_{2}: \mathrm{Al}_{72} \mathrm{Mn}_{16} \mathrm{Zn}_{12}$, and $\tau_{3}$ : $\mathrm{Al}_{x} \mathrm{Mn}_{y} \mathrm{Zn}_{z}$ ( $x=9-13$ at $\% ; y=11-15$ at $\% ; z=75-77$ at\%). A single-phase region of $\mathrm{Al}_{8} \mathrm{Mn}_{5}$ with extended solubility was found in this system at $400^{\circ} \mathrm{C}$. Based on the current findings, the ternary solubilities of the $\mathrm{Al}_{8} \mathrm{Mn}_{5}, \mathrm{Al}_{4} \mathrm{Mn}$, and $\mathrm{Al}_{11} \mathrm{Mn}_{4}$ compounds have been determined as 10 at $\%, 6$ at $\%$, and 4 at $\%$ $\mathrm{Zn}$, respectively. $\varepsilon$ and $\mathrm{Mn}_{5} \mathrm{Zn}_{21}$ exhibit their maximum solubilities of 4 at $\%$ and 5 at $\%$ Al. The solubility of $\mathrm{Zn}$ in $\beta-\mathrm{Mn}^{\prime}$ has been found to be 4 at $\%$ and $\beta-\mathrm{Mn}^{\prime \prime}$ has ternary solubility of 3 at $\% \mathrm{Al}$.

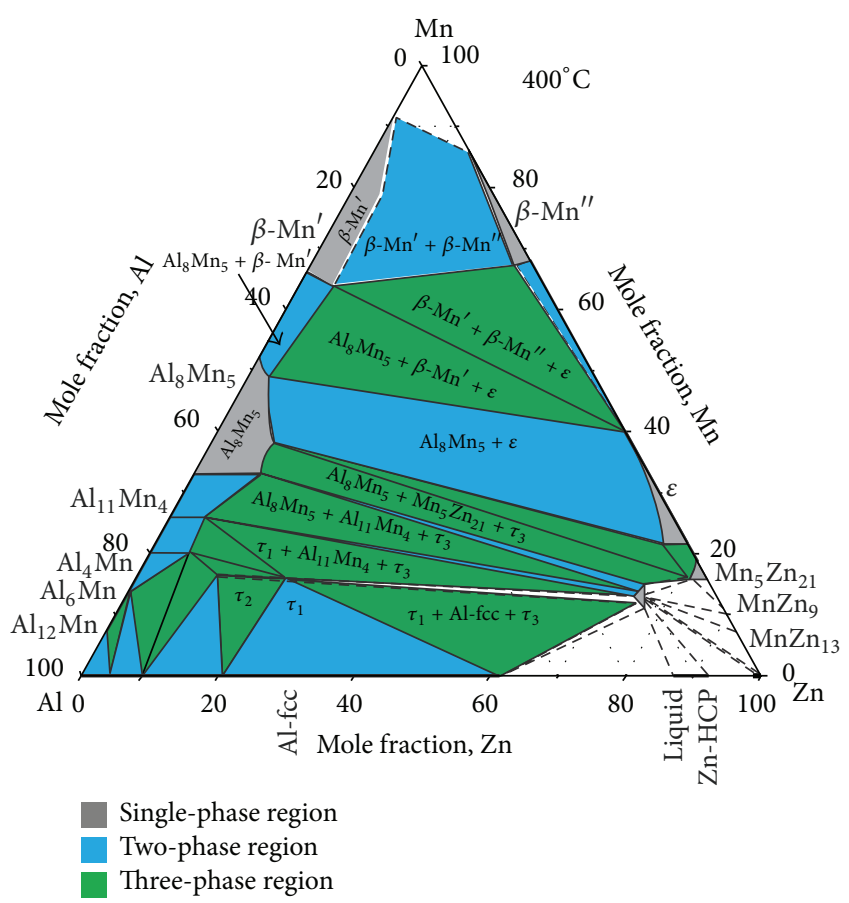

FIgURE 14: Isothermal section of Al-Mn-Zn ternary system at $400^{\circ} \mathrm{C}$ constructed by diffusion couples and key samples.

\section{Conflict of Interests}

The authors declare that there is no conflict of interests of any sort that might have influenced the discussions or conclusions of this paper.

\section{Acknowledgments}

Financial support from General Motors of Canada Ltd. and the Natural Sciences and Engineering Research Council of Canada (NSERC) through the CRD grant program is gratefully acknowledged. The authors would also like to acknowledge the help of Mohammad Mezbahul-Islam of Mechanical Engineering Department, Concordia University, for his valuable suggestions.

\section{References}

[1] G. S. Cole and A. M. Sherman, "Light weight materials for automotive applications," Materials Characterization, vol. 35, no. 1, pp. 3-9, 1995.

[2] S. W. Nam and B. O. Kong, "Development of weldable high strength alalloy," KOSEF Technical Report, 1993.

[3] H. S. Cho and S. W. Nam, "A study of the low cycle fatigue properties of weldable Al-Zn-Mg-Mn Alloy and Al 7039 in various environments," Journal of Korean Institute of Metals and Materials, vol. 32, no. 7, pp. 765-770, 1994.

[4] M. Ohno, D. Mirkovic, and R. Schmid-Fetzer, "Liquidus and solidus temperatures of Mg-rich $\mathrm{Mg}-\mathrm{Al}-\mathrm{Mn}-\mathrm{Zn}$ alloys," Acta Materialia, vol. 54, no. 15, pp. 3883-3891, 2006.

[5] N. Gao, Y. H. Liu, and N.-Y. Tang, "An experimental study of the liquid domain of the $\mathrm{Zn}-\mathrm{Fe}-\mathrm{Al}-\mathrm{Mn}$ quaternary system at 
$460^{\circ}$ C," Journal of Phase Equilibria and Diffusion, vol. 31, no. 6 , pp. 523-531, 2010.

[6] M. A. Khan and M. Medraj, "Thermodynamic description of the Mg-Mn, Al-Mn and Mg-Al-Mn systems using the modified quasichemical model for the liquid phases," Materials Transactions, vol. 50, no. 5, pp. 1113-1122, 2009.

[7] C. Müller, H. Stadelmaier, B. Reinsch, and G. Petzow, "Metallurgy of the magnetic $\tau$-phase in $\mathrm{Mn}-\mathrm{Al}$ and $\mathrm{Mn}$-Al-C," Zeitschrift fuer Metallkunde, vol. 87, no. 7, pp. 594-597, 1996.

[8] A. Shukla and A. D. Pelton, "Thermodynamic assessment of the Al-Mn and Mg-Al-Mn systems," Journal of Phase Equilibria and Diffusion, vol. 30, no. 1, pp. 28-39, 2009.

[9] H. Kono, "On the ferromagnetic phase in manganesealuminum system," Journal of the Physical Society of Japan, vol. 13, no. 12, pp. 1444-1451, 1958.

[10] W. Koster and E. Wachtel, "Constitution and magnetic properties of aluminum-manganese alloys with more than 5 At. \% Mn," Zeitschrift fuer Metallkunde, vol. 51, pp. 271-280, 1960.

[11] Y. Minamino, T. Yamane, H. Araki et al., "Solid solubilities of manganese and titanium in aluminum at $0.1 \mathrm{MPa}$ and 2.1 GPa," Metallurgical Transactions A, vol. 22, no. 3, pp. 783-786, 1991.

[12] H. Okamoto, "Al-Mn (Aluminum-Manganese)," Journal of Phase Equilibria, vol. 18, no. 4, pp. 398-399, 1997.

[13] M. A. Taylor, "Intermetallig phases in the aluminiummanganese binary system," Acta Metallurgica, vol. 8, no. 4, pp. 256262, 1960.

[14] S. Wasiur-Rahman and M. Medraj, "A thermodynamic description of the Al-Ca-Zn ternary system," Calphad, vol. 33, no. 3, pp. 584-598, 2009.

[15] H. Okamoto and L. E. Tanner, "The Mn-Zn (Manganese-Zinc) system," Bulletin of Alloy Phase Diagrams, vol. 11, no. 4, pp. 377384, 1990.

[16] S. Tezuka, S. Sakai, and Y. Nakagawa, "Ferromagnetism of MnZn alloy," Journal of the Physical Society of Japan, vol. 15, no. 5, p. 931, 1960.

[17] Y. Nakagawa and T. Hori, "Magnetic transition and crystal distortion in $\mathrm{MnHg}$ and $\mathrm{MnZn}_{3}$," Journal of the Physical Society of Japan, vol. 17, no. 8, pp. 1313-1314, 1962.

[18] B. Henderson and R. J. M. Willcox, "Lattice spacing relationships in hexagonal close-packed Silver-Zinc-Manganese alloys," Philosophical Magazine, vol. 9, no. 101, pp. 829-846, 1964.

[19] R. A. Farrar and H. W. King, "Axial ratios and solubility limits of H.C.P. $\eta$ and $\varepsilon$ phases in the systems CdMn and ZnMn," Metallography, vol. 3, no. 1, pp. 61-70, 1970.

[20] J. L. Liang, Y. Du, C. Z. Liao et al., "Experimental investigation on the phase equilibria of the $\mathrm{Mn}-\mathrm{Ni}-\mathrm{Zn}$ system at $400^{\circ} \mathrm{C}$," Journal of Alloys and Compounds, vol. 489, no. 2, pp. 362-368, 2010.

[21] J. L. Liang, Y. Du, Q. Z. Zhao et al., "Determination of the phase equilibria in the Mn-Sn-Zn system at $500^{\circ}$ C," Metallurgical and Materials Transactions A: Physical Metallurgy and Materials Science, vol. 40, no. 12, pp. 2909-2918, 2009.

[22] H. Xu, X. Xiong, L. Zhang, Y. Du, and P. Wang, "Phase equilibria of the Mn-Si-Zn system at $600^{\circ} \mathrm{C}$," Metallurgical and Materials Transactions A: Physical Metallurgy and Materials Science, vol. 40, no. 9, pp. 2042-2047, 2009.

[23] E. Gebhardt, "Die zinkecke des dreistoffsystems zinkaluminium-mangan," Zeitschrift für Metallkunde, vol. 34, pp. 259-263, 1942.

[24] G. V. Raynor and D. W. Wakeman, "The intermetallic compound phases of the system Aluminium-Manganese-Zinc,"
Proceedings of the Royal Society of London A: Mathematical and Physical Sciences, vol. 190, no. 1020, pp. 82-101, 1947.

[25] K. Robinson, "The determination of the crystal structure of $\mathrm{Ni}_{4} \mathrm{Mn}_{11} \mathrm{Al}_{60}$, Acta Crystallographica, vol. 7, part 6-7, pp. 494497, 1954.

[26] A. Damjanovic, "The structure analysis of the $\mathrm{T}_{3}$ (A1MnZn) compound," Acta Crystallographica, vol. 14, pp. 982-987, 1961.

[27] R. J. Schaefer, L. A. Bendersky, D. Shechtman, W. J. Boettinger, and F. S. Biancaniello, "Icosahedral and decagonal phase formation in Al-Mn Alloys," Metallurgical transactions A, vol. 17, no. 12, pp. 2117-2125, 1986.

[28] A. Singh, S. Ranganathan, and L. A. Bendersky, "Quasicrystalline phases and their approximants in Al-Mn-Zn alloys," Acta Materialia, vol. 45, no. 12, pp. 5327-5336, 1997.

[29] J. S. Kirkaldy and L. C. Brown, "Diffusion behavior in the ternary, multiphase systems," Canadian Metallurgical Quarterly, vol. 2, no. 1, pp. 90-115, 1963.

[30] J. B. Clark, "Conventions for plotting the diffusion paths in multiphase ternary diffusion couples on the isothermal section of a ternary phase diagram," Transactions of the Metallurgical Society of AIME, vol. 227, pp. 1250-1251, 1963.

[31] A. A. Kodentsov, G. F. Bastin, and F. J. J. van Loo, "The diffusion couple technique in phase diagram determination," Journal of Alloys and Compounds, vol. 320, no. 2, pp. 207-217, 2001.

[32] M. A. Khan, Thermodynamic modeling of the $\mathrm{Mg}-\mathrm{Mn}-(\mathrm{Al}, \mathrm{Zn})$ systems [M.S. thesis], Concordia University, 2009.

[33] PANalytical, Ver2.2b (2.2.2), PANalytical, Almelo, The Netherlands, 2006.

[34] H. Putz and K. Brandenburg, Pearson's Crystal Data, Crystal Structure Database for Inorganic Compounds, CD-ROM Software Version 1.3.

[35] P. Ghosh and M. Medraj, "Thermodynamic calculation of the $\mathrm{Mg}-\mathrm{Mn}-\mathrm{Zn}$ and $\mathrm{Mg}-\mathrm{Mn}$-Ce systems and re-optimization of their constitutive binaries," Calphad: Computer Coupling of Phase Diagrams and Thermochemistry, vol. 41, pp. 89-107, 2013.

[36] A. Prince, Alloy Phase Equilibria, Elsevier, Amsterdam, The Netherland, 1966.

[37] L. Y. H. John, "Schreinemakers rule as applied to nondegenerate ternary systems," The Journal of Young Investigators, vol. 19, no. 11, 2009. 

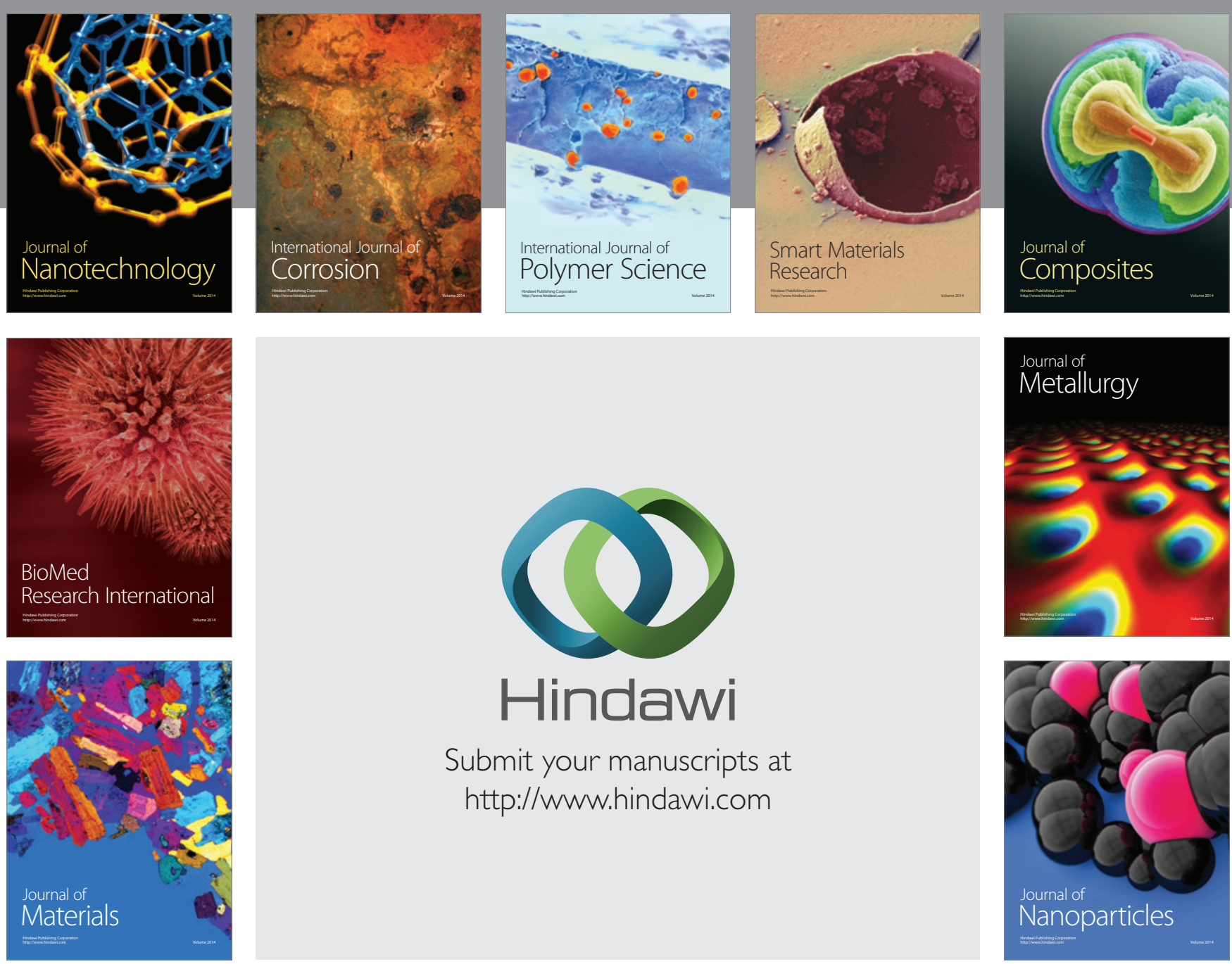

Submit your manuscripts at http://www.hindawi.com
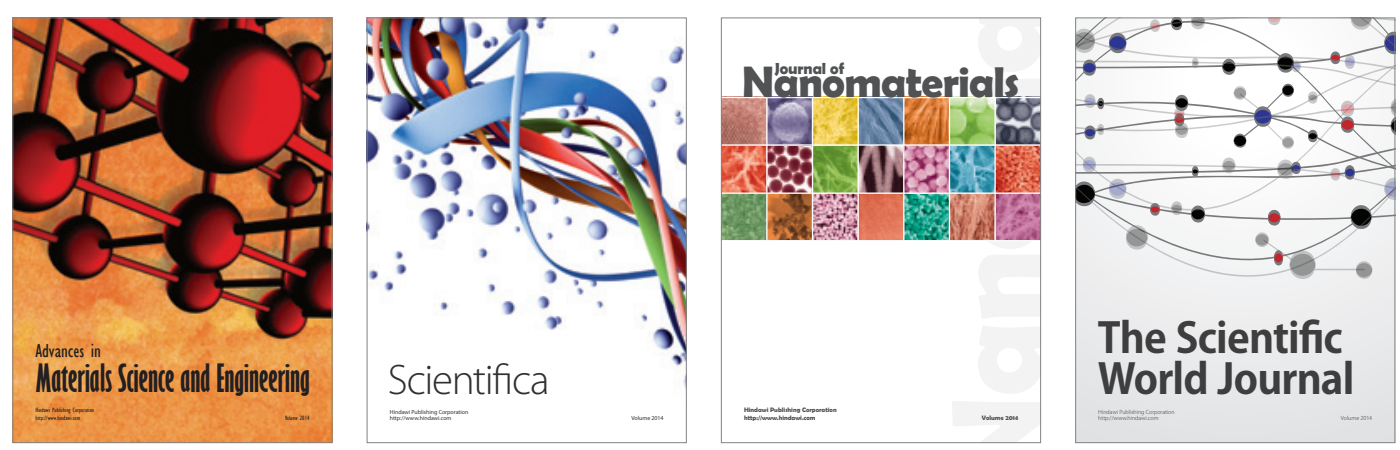

\section{The Scientific World Journal}
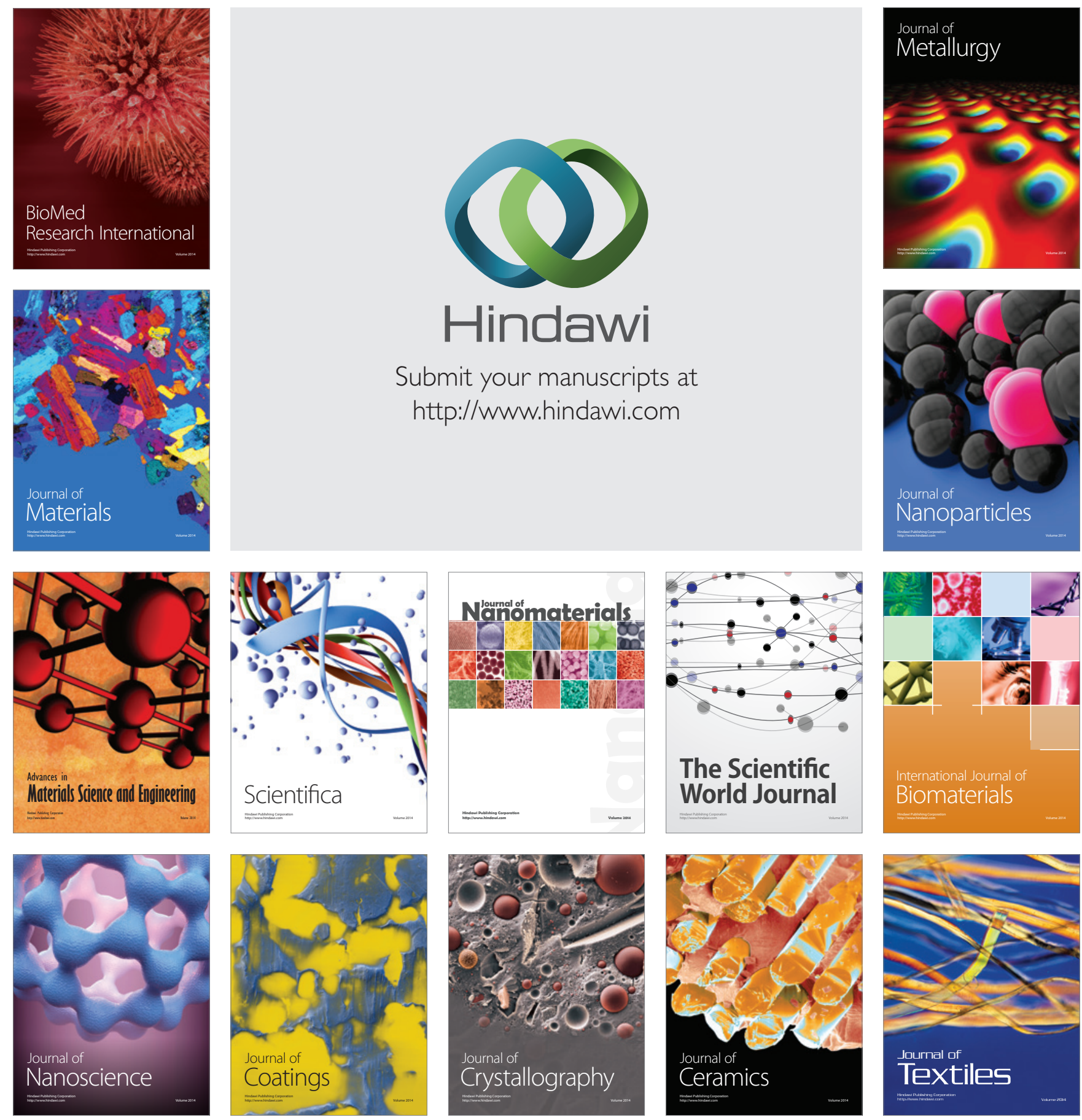